\title{
Sobre la condición de los conversos y chuetas de Mallorca
}

\author{
Álvaro Santamaría Arández*
}

\begin{abstract}
RESUMEN
ABSTRACT

El asalto a la judería mallorquina en 1391

The assault o the majorcan jewish provocó una conversión masiva de judíos al cristianismo, que tuvo su continuación en el año 1435, cuando en circunstancias singulares se cristianizó la totalidad de la aljama y se prohibió la residencia de judíos en Mallorca. Los conversos continuaron ejerciendo mayoritariamente actividades de carácter mercantil y artesanal, y mantenían estrechos lazos de solidaridad. Entre 1488 y 1516 sufrieron la acción de la nueva Inquisición, siendo muy elevado el número de reconciliados y relajados; pero entre 1517 y 1673 disminuyó considerablemente la actividad inquisitorial contra conversos acusados de judaizantes. A mediados del siglo XVII

la comunidad conversa o chueta presentaba una gran cohesión, residia mayoritariamente en la parroquia de Santa Eulalia, en pleno centro comercial, y se dedicaba en su mayor parte a quarter in 1391 forced a massive conversion of jewish to christianism, as it happened later in 1435, when under singular circumstances, the entire "aljama" was cristianized and the residence of jewish in Majorca was forbidden. The converts continued their activities, mainly in the fields of trade and craftmanship, while mainteining strong solidarity among them. Between 1488 and 1516 they suffered the action of the new Inquisition, increasing the number of jewish reconciled or weakened; but between 1517 and 1673 there was a considerable decrease of the Inquisition action against converts accused of judaizing. In the middle of the XVII century, the community of converts, also known as chuetas, was very cohesive, they lived mainly in the quarter of Santa Eulalia, the trade centre, and worked principaly
\end{abstract}

* Profesor Emérito. Universidad de las Islas Baleares. 
actividades artesanales y mercantiles.

Pero los autos de fe de 1679 y 1691 , reflejo de un ambiente de creciente intolerancia y violencia hacia los conversos, ahondaron la brecha existente entre las comunidades chueta $y$ cristiano vieja, prolongando hasta la contemporaneidad en la sociedad mallorquina un problema que deberia haber desaparecido mucho tiempo antes. in trade and craftmanship. But the "autos de fe" of 1679 and 1691, as a result of a growing atmosphere of violence and intolerance towards converts, deeped the gap between the community of old christians and the chuetas, prolonging until recent times in the Majorcan society, the existence of a problem that should had disappeared long time ago.

\section{EL TEMA, LA BIBLIOGRAFÍA Y LAS FUENTES}

El apelativo despectivo chueta y los disminutivos derivados chuetó y chuetona -en lengua mallorquina "xueta», "xuetó», "xuetona»-, creación del habla popular de los cristianos viejos de Mallorca, se han aplicado desde fines del siglo XVIII, dichos con intención difamatoria a modo de estigma infamante, en el significado de judío, judihuelo y judihuela, para designar a los descendientes de judíos cristianizados, procesados como presuntos judaizantes y reconciliados por la Iglesia o relajados al brazo secular por el Santo Oficio en los autos de fe celebrados en Mallorca en 1679 y 1691 . Términos dichos con el propósito de trasmitir una imagen negativa de tales descendientes, mirados como gentes ruínes, logreras, hipócritas, solapadas, pérfidas y en suma despreciables 1.

Tales expresiones, se emplearon en el lenguaje coloquial desde fines del siglo XVII y en relación con los mentados autos de fe, que afectaron a centenares de presuntos judaizantes y determinaron una fractura traumática de trascendentales secuelas en la convivencia y en el devenir de la sociedad mallorquina. En los siglos XIV, XV y XVI los cristianos viejos, aunque trataran a los judeoconversos con desconfianza y recelo les conocían como "crestians novells» o como conversos, pero en el curso del siglo XVII, un siglo negro en la historia de Mallorca, de creciente intolerancia y suma violencia, comenzó a designarse a los conversos con la locución «des carrer del Sagell» o «des carrer», de la calle, porque enton-

\footnotetext{
En los autos tramitados en 1688 se alude a los que «comunamente Ilaman xuetas», en el sentido de "cristianos nuevos de conversos de judíos", expresión "xueta» que se reitera a partir de 1688 en documentos del Consejo Supremo de la Inquisición. La grafía "chueta» se encuentra por primera vez, al decir de Ángela Selke, en el segundo proceso de Rafael Joachim Valls del año 1722 , en el que el reo contestando a la pregunta «de qué casta y generación son sus padres» dice «todos han sido de la calle del Sagell que vulgarmente llaman chuetas». En cualquier caso el término "xueta" o chueta se consolidó a partir de los procesos incoados en 1679.
} 
ces la calle del Sagell -del Sello-, con las de Argentería y Bolsería, en el cogollo del centro comercial urbano, eran vías principales de la chuetería, del barrio de los judeoconversos 2 . Los términos "xueta" y "des carrer» conservan vigencia en el lenguaje de Mallorca pero sin la carga peyorativa del pasado.

El tema de los chuetas de Mallorca ha suscitado una interesante bibliografía, encabezada por el padre Francisco Garau, calificador del Santo Oficio, examinador sinodal diocesano y rector del colegio de Montesión de la compañía de Jesús, que asistió espiritualmente a reos condenados a muerte por judaizar y escribió y publicó a vuela pluma, "casi en medio del susto", según dice, aquel año de 1691, año de las hogueras inquisitoriales, La Fe Triunfante, crudo relato de lo acontecido y sus circunstancias, escrito para «perpetua memoria del suceso y preservativo escarmiento». La Fe Triunfante, vituperada por los descendientes de los judeoconversos y en general por la historiografía como nefasto libelo infamante, porque exalta acaeceres inicuos sólo merecedores del olvido, fue celebrada por los cristianos viejos como expresión de la vitalidad del catolicismo militante de la sociedad de Mallorca, defensora de la fe y de la ortodoxia y debeladora y extirpadora de herejías y errores judaicos ${ }^{3}$.

La interpretación historiográfica de que las referencias contenidas en La Fe Triunfante determinaron la perduración en Mallorca de la animadversión cristianos viejos/conversos, que motivó la discriminación laboral y la marginación social de los chuetas, es interpretación desmesurada, porque las raíces de dicha animadversión y mutuo rechazo eran seculares, ya que ciertas abominables reflexiones y juicios de valor, el padre Garau los formuló en sintonía con sentimientos y mentalidades mayoritarias, de hechura inquisitorial, de los cristianos viejos y, sobre todo, porque lo que determinó la perduración fue el trauma de los autos de fe de 1691, los más sanguinarios de la historia del Santo Oficio en Mallorca, en la sociedad mallorquina. El relato del padre Garau, al margen de su apasionado testimonio y de sus reprobables juicios de valor, por la valiosa información que aporta es un referente sociológico importante, en la medida que contribu-

2 La locución «carrer del Sagelt» utilizada en el lenguaje coloquial está documentada en una proposición del “jurat en cap» don Pedro de Verí formulada en 1671 a sus compañeros de juraduría: «Se ha de remediar algunas cosas en la forma (de recaudar) del dret del Sagell (derecho del Sello) que son en dany dels particulars y profit dels del carrer del Sagell» (AHM, EU 79, fol. 219 v.).

${ }^{3}$ La fe triunfante en cuatro autos de fe. Dedicada a los magníficos señores jurados de la ciudad y reino de Mallorca. Mallorca, Imprenta de la viuda Guasp, 1691. Reeditada en 1755 y en 1931 (Palma de Mallorca, Establecimiento tipográfico de J. Tous, 1931). 
ye al mejor conocimiento y comprensión de los aconteceres. El que tales aconteceres sean aflictivos y merezcan plena repulsa, es otro cantar.

En torno a 1847, probablemente, se elaboraron los Anales Judaicos de Mallorca, obra anónima atribuida, a mi parecer certeramente, por Lorenzo Pérez a Félix Ponzoa y Cebrián, natural de Murcia, administrador de la Aduana de Palma de 1845 a 1848 y amigo íntimo del infatigable historiador-anticuario y proclive fabulador don Joaquín María Bover, con el que colaboró en la confección del Diccionario Manual para el estudio de las antigüedades, impreso en 1846. Los Anales, revelan las andanzas por Mallorca de un curioso visitante, y discurren en tono burlesco sobre tópicos y prejuicios antichuetas y recopilan noticias carentes de rigor sobre judíos y conversos de Mallorca del siglo I a mediado el siglo XIV. Los Anales, son paradigma de la literatura antichueta pero la notable Introducción, el denso aparato de notas informativas y el apéndice Ensayo de un inventario de judíos mallorquines condenados por la Inquisición (1478-1720), obra erudita de Lorenzo Pérez, transcriptor de los Anales, merecen reconocimiento ${ }^{4}$.

En otro lenguaje y con cierta frivolidad conceptual, Juan de la Puerta Vizcaíno menciona con brevedad en La Sinagoga Balear, publicada en 1857 , datos y noticias sobre judíos y conversos desde la llegada de los judíos a Mallorca a fines del siglo XVII, e inserta la relación de penitenciados en los autos de fe de 1691, trasunto textual sin citarlo del padre Garau, completada de su cosecha con una Relación de sambenitos puestos en 1755 en el claustro del convento de San Francisco de Palma ${ }^{5}$.

Mediado el siglo XIX la relación cristianos viejos/descendientes de conversos, no acusaba la tensa crispación de antaño, contemplada por los forasteros como extraña singularidad social que los naturales, en general, procuraban soslayar discretamente. Por ello determinó cierta sorpresa que un joven chueta la abordara frontalmente. José Tarongí y Cortés, ordenado sacerdote en 1876 y que, a tenor de una letra testimonial de don Mateo Jaume y Garau obispo de Mallorca, había aprobado por unanimidad los ejercicios literarios de la oposición a la canongía lectoral de la catedral de Palma, insertó en el Almanaque Balear de 1877, el artículo Libros malos y cosas peores, en el que denunciaba con energía y lenguaje directo las denominadas "preocupaciones de clase" de Mallorca, fustigando

4 Anales judaicos de Mallorca. Transcripción, introducción y notas por Lorenzo PÉREz. Luĺs Ripoll editor. Palma de Mallorca, 1974.

5 La Sinagoga Balear. Historia de los judios de Mallorca. Imprenta de la Regeneración Tipográfica. Valencia, 1857. Edición facsímil. Editorial Clumba. Palma de Mallorca, 1951. 
en particular la postura del clero, en abierta contradicción con los principios de equidad cristianosocial y con las doctrinas de la Iglesia.

Gentes acomodadas «des carrer» manifestaron privadamente a Tarongí sus reparos, no en cuanto a la substancia de la cuestión, que padecían resignadamente en sus carnes, sino respecto a la oportunidad de plantearla entonces, cuando la tensión estaba moderándose, y por el tono y la crudeza expositiva, y cinco sacerdotes "des carrer» se apresuraron a patentizar ante el obispado su disconformidad con el fondo y la forma del artículo. Fue el comienzo de una apasionada polémica protagonizada por el sacerdote don Miguel Maura que expuso con erudición sus objeciones en Una buena causa mal defendida, replicada con contundencia por Tarongí en el alegato Una mala causa a todo trance defendida, polémica que encontró eco en la prensa periódica de toda España ${ }^{6}$. Al año siguiente, 1878, don José Tarongí, tras la reglamentaria oposición, fue nombrado canónigo de la Colegiata del Sacromonte de Granada.

Don José María Quadrado, distante de las «preocupaciones de clase» y amistosamente relacionado con patricios chuetas como don Tomás Aguiló, ambos aunados por una común devoción al estudio de la historia y a la defensa del catolicismo, publicó La judería de la capital de Mallorca en 1391, año del saqueo y destrucción del Call de Mallorca, que incluye una relación de un centenar largo de judeoconversos propietarios de viviendas de la judería? Aprovechando fondos documentales del Archivo Histórico Nacional don Julián Paz elaboró en 1906 el estudio Reclamaciones de los mallorquines llamados de la Calle, sobre el litigio entre la comunidad de conversos de Mallorca y las Instituciones de Mallorca ${ }^{8}$. Los documentos del referido litigio, muy importantes, están publicados en el volumen Reivindicación de los judíos de Mallorca ${ }^{9}$, y también están publicadas las Memorias remitidas al Consejo Supremo de la Inquisición por el licenciado José Huarte inquisidor de Mallorca el 13 de febrero de 1693,

6 Tarongí publicó la polémica en el libro Algo sobre el estado religioso y social de la isla de Mallorca. Polémica contra las preocupaciones de clase. Imprenta Bartolomé Rotger. Palma, 1877. Después recopiló los juicios sobre el libro de la prensa española en el volumen Sobre la cuestión social mallorquina y sobre el libro de polémica titulado Estado religioso y social de la isla de Mallorca. Imprenta Bartolomé Rotger. Palma, 1878.

7 Publicado en el «Boletín de la Real Academia de la Historia». Cuaderno IV del tomo IX (octubre de 1886), reproducido en «Museo Balear». Época II, tomo IV, núm. 8 (abril de 1887). Edición prolongada por Juan Muntaner Bujosa, La judería de Mallorca en el siglo XV. Imprenta de mossèn Alcover. Palma de Mallorca, 1967.

8 Julián PAZ, Reclamaciones de los mallorquines llamados de la calle sobre su condición social. Revista de Archivos, Bibliotecas y Museos, 16 (1907), págs. 184-200.

9 Reivindicación de los judíos mallorquines. Presentación de Lorenzo PÉrEz, Introducción de Francisco Rivera. Fontes Rerum Balearium. Palma de Mallorca, 1983. 
con la relación nominal y datos esenciales sobre reconciliados y relajados por la Inquisición de Mallorca de 1488 a $1691^{\text {to. }}$.

Los fondos documentales sobre la Inquisición de Mallorca custodiados en el Archivo Histórico Nacional, en particular los procesos de fe incoados en 1679 a 1688, han sido parcialmente investigados por Baruch Braunstein al elaborar su notable tratado Los chuetas de Mallorca, en el que diseña una panorámica global discretamente construida y bien documentada de la problemática de los judíos y conversos mallorquines hasta la contemporaneidad ${ }^{11}$. Tiene mayor enjundia la sugestiva aportación de Ángela Selke, Los chuetas y la Inquisición, que evidencia su dominio de la bibliografía y el aprovechamiento inquisitivo y perspicaz de las testificaciones de reos de las causas de fe, fuente de variada e interesante información sobre aspectos de la cotidianeidad del barrio converso en el seiscientos. La obra, secuencia de una amplia y atenta investigación y con una articulación temática racional, ofrece una exposición lúcida y esencial de la problemática ${ }^{12}$.

El estudio de don Miguel Forteza, Els descendents de juheus conversos de Mallorca, es meritorio y su subjetividad es comprensible, pero como se deduce de los datos aportados por Braunstein, conocidos por el señor Fortaza, procede admitir que parte de los conversos, probablemente según entiendo muy minoritaria, judaizaban ${ }^{13}$. La monografía de Francesc Riera, Lluites antixuetes en el segle XVIII, bien documentada, es otra interesante y notable aportación sobre todo respecto a las circunstancias que condicionaban mayormente las relaciones humanas de los chuetas ${ }^{14}$.

Los estudiosos han otorgado mayor atención en su quehacer investigador al fondo documental del Archivo Histórico Nacional por su mayor relevancia, en particular en las series Relación de causas de fe (años

10 Inquisición de Mallorca. Reconciliados y relajados. M.P. Barcelona, 1946. Braunstein en la obra citada en la nota 11 insertó en 1936 la Relación en el Apéndice 2 «Reconciliations and reflaxations», págs. 139-181; y posteriormente Lorenza Pérez en 1974 continuó la Relación ordenada alfabéticamente en el Apéndice de Anales Judaicos de Mallorca (nota 4).

11 Baruch BraunsteIN, The chuetas of Majorca. Conversos and the Inquisition of Majorca. Columbia University, Oriental Series, vol. 28. N.Y., 1936. Nueva edición. N.Y., 1972. Traducción inédita castellana de Miguel Aguiló, Los chuetas de Mallorca. Palma de Mallorca, 1943. Traducción al catalán de Roger ALIER, Els xuetes de Mallorca. Els conversos i la Inquisició de Mallorca. Barcelona, 1976.

12 Los chuetas y la Inquisición. Vida y muerte en el ghetto de Mallorca. Taurus ediciones. Madrid, 1972.

13 Els descendents de juheus conversos de Mallorca. Quatre mots de la veritat. Gráficas Miramar. Palma de Mallorca, 1966.

14 Lluites antixuetes en el segle XVII. Editorial Moll. Mallorca, 1983. 
1579-1690) y Legajos de causas de fe, que reúne casi un centenar de procesos (legajos 1705-1715), casi todos de los años 1672 a 1673; pero no merecen menos consideración los fondos del Archivo del Reino de Mallorca, si bien ofrecen la dificultad de su dispersión, en series de contenido muy diverso y variopinto como las Deliberacions del Consell General (DGG), Lletres misives (LM), Extraordinaris de la Universitat (EU) y Lletres reals (LR) registros de los años 1485-1715, Protocolos notariales (Contratos y testamentos) y Legajos del Real Acuerdo. Dicha dificultad no afecta al depósito más importante por su volumen y su contenido, los Fondos del Tribunal de la Inquisición de Mallorca, recientemente catalogados por María José Massot de Ayreflor, constituidos principalmente por diligencias de secuestro y confiscación de bienes, cabreves de judaizantes y registros de administración y contabilidad de la Inquisición de Mallorca. Importa también considerar la documentación del Archivo Municipal de Palma, del Archivo Diocesano de Mallorca y del Archivo del Cabildo de Mallorca ${ }^{15}$.

\section{LOS CONVERSOS DE 1391}

En la jornada del 2 de agosto de 1391, la judería de la ciudad de Mallorca, de las más populosas del Mediterráneo (casi 2.500 almas en 1364), quedó desvastada y destruida. «Hombres de las villas de la parte foránea con muchos y diversos hombres de la ciudad -anotó en uno de sus protocolos el notario Mateo Salzet testigo de la invasión- entraron en el call judaico y lo arrasaron. En la invasión fueron muertos unos 300 judíos entre hombres y mujeres". Fue un holocausto sin precedentes en el devenir histórico de Mallorca, salvo el genocidio de musulmanes perpetrado por los asaltantes cristianos al tomar la ciudad de Mallorca el 31 de diciembre de 1229.

El gobernador Francisco Sagarriga, noticioso de que una multitud de campesinos de las villas estaban extramuros de la ciudad pretendiendo

\footnotetext{
15 He trabajado sobre la problemática de los conversos y los judíos de Mallorca en los siguientes estudios:

- En torno a la situación de los judíos conversos de Mallorca en el siglo Xv. En «Boletín de la Sociedad Arqueológica Luliana», XXXI. Palma de Mallorca (1955), págs. 3-15.

- Mallorca en el siglo xIv. En "Anuario de Estudios Medievales», 7, 1970-1971, págs. 172-225.

- Instauración de la nueva Inquisición en Mallorca. En cHomenaje al Dr. Juan Reglà Campiscol», vol. I. Universidad de Valencia, 1975, págs. 173-185.

- Sobre la aljama de Mallorca: el impuesto «sizè del vin juheuesch», 1400-1435. En «La España Medieval». Editorial Universidad Complutense. Madrid, 1981, págs. 467-494.
} 
forzar la entrada, trató de disuadirles pero resultó maltratado y herido, no se sabe si por los campesinos o por gentes populares que desde dentro de la ciudad apoyaban a los campesinos. "Tots jueus e juies del call judaich - comunicó luego Sagarriga - foren robats e alguna partida de aquells cruelment morts. Diversos colps e nafres foren perpetrades en nostra persona».

La destrucción del Call de Mallorca, se enmarca en la oleada antisemita que se manifestó en España, y sólo en España, entre el 6 de junio (saqueo de la judería de Sevilla) y el 13 de agosto (saqueo de la judería de Lérida), y que devastó en el nefasto verano de 1391 buena parte de la juderías de la Corona de Castilla y de la Corona de Aragón.

Pero en Mallorca aquel año, como en ocasiones anteriores, los judíos fueron víctimas de tensiones sociales más profundas, denotadas en el hondo desasosiego del campesinado de las villas y de los menestrales de la ciudad, disgustados por los elevados impuestos, el crecimiento de la deuda pública, la mala gestión administrativa, y el desgobierno generalizado. Por ello tras saquear la judería en la sangrienta jornada del 2 de agosto, los campesinos de la ciudad y los populares de las villas intentaron asaltar la Sala de la Juraduría, es decir, el consistorio, sede de los jurados y del Consell General, y saquearon casas de miembros de la oligarquía urbana, objeto de su encono.

El gobernador y los jurados, desbordados, se allanaron a las exigencias de los amotinados. Abolieron, "de tot en tot", todos los impuestos y se comprometieron a inhabilitar perpetuamente a los que hubieran desgobernado la cosa pública y a apoyar una reforma de la planta del Consell General, para que la representación de los campesinos y los menestrales se igualara a la representación de los mercaderes, los ciudadanos y los caballeros. Pese a dichas concesiones a fines de septiembre miles de campesinos, se decía que unos 5.000, otra vez amotinados, acamparon en los alrededores de la ciudad, ocasionando graves daños, para exigir nuevas peticiones que, como las anteriores, nada tenían que ver con la problemática de los judíos, cabeza de turco de una conflictividad extraña a su comunidad.

En la negra jornada del 2 de agosto, centenares de judíos escapados a tiempo de la judería se refugiaron en el castillo real de la Almudayna, donde se retiró el gobernador herido en la contienda, custodiado el castillo por ballesteros al mando del pelaire Antoni Matas. En tal situación de emergencia, y presionados por el griterío de jconversión o muerte! de cientos de amotinados, parte de los judíos refugiados a los que los jurados de Mallorca comunicaron que «si se feyen crestians la ciutat pagaria 
en descarrech de lurs deutes 20.000 lliures de reyals de Mallorques", se cristianizaron.

¿Cuántos judíos se cristianizaron? Están identificados 111 conversos de los que consta el antiguo nombre judío y el nuevo nombre cristiano (por ejemplo, el célebre cartógrafo mallorquín Jahuda Cresques se cristianizó como Jacobus Ribes), pero el número de cristianizados tuvo que ser mayor, probablemente mucho mayor, ya que la expresada identificación sólo se refiere a los conversos propietarios de una o más viviendas en la devastada judería, que convocados por el gobernador se personaron en la curia de Gobernación, en la Almudayna, durante el mes de octubre de 1391, para declarar su intención de habitar o arrendar o vender su casa o casas.

La judería se emplazaba al sudeste de la ciudad, en el lugar asignado por Jaime II de Mallorca el año 1300, en el marco de su programa de remodelado urbano, y constituía un recinto cerrado, con tres portales denominados del Temple, de Santa Fe y de la Calatrava, y una puerta conocida por Puerta mayor del Call, que comunicaba la judería con el centro urbano, en el entorno de la plaza Santa Eulalia. De los tres citados portales arrancaban tres ejes de tráfico, por el trazado de las actuales calles Sol, Montesión y Calatrava-San Alonso, enlazadas dichas calles por callejas y callejones colaterales, algunos sin salida, y las tres calles confluían en la plaza Mayor del Call, inmediata a la Puerta mayor del Call.

Al este del Call, a la vera de la fortaleza del Temple, colindante con el huerto del Temple, se ubicaba la casa del cartógrafo Jahuda Cresques, una casa grande, la única del Call calificada en el registro como «magnum hospitium». El 30 de octubre de 1391 Jahuda, en su nueva identidad de Jaume Ribes, se presentó en la curia de Gobernación, como estaba mandado, para manifestar que la casa era de su propieclad y que seguía en duda y no sabía si la habitaría o la arrendaría.

La ayuda de 20.000 libras ofrecida por los jurados a los judíos que se cristianizaran, aunque la reclamaron, nunca se pagó, como era de esperar, pues ni la Administración disponía de recursos ni habrían tolerado los campesinos y los menestrales semejante dispendio, que interpretarían como una provocación. No sólo no llegó la ayuda, sino que la Administración requirió de los conversos el pago de un «donatiu» a la Corona, pagadero probablemente también por los judíos, equivalente a un 20 por 100 del patrimonio de la comunidad conversa.

Eran tiempos de precariedad e incertidumbre para todos y especialmente para los conversos y los judíos sobrevivientes. Saqueados sus haberes y desvastadas sus casas, sin poder mercadear por las villas ni salir 
de Mallorca para comerciar sin licencia especial del gobernador, y acosados por el recelo de la comunidad cristiana, los que pudieron emigrar burlando las severas medidas adoptadas para evitarlo, escaparon de Mallorca.

La situación se normalizó lentamente. Un bando del gobernador, publicado el 20 de diciembre de 1391, comunicó que el rey Juan I anulaba las concesiones otorgadas a petición de los campesinos de las villas y de los populares de la ciudad, por ser concesiones ilegítimas, exigidas bajo coacción y con extrema violencia. El 12 de octubre de 1392, juzgados y ejecutados 15 de los amotinados por delitos perpetrados en la devastación de la judería y durante las perturbaciones posteriores, la reina Violante concedió un indulto general, que sólo excluía a los que el 2 de agosto habían atentado contra la vida del gobernador Sagarriga.

No fue un indulto gracioso, gratuito, pues su aplicación estaba condicionada al pago de una muy cuantiosa sanción económica de 120.000 florines, equivalente a 90.000 libras moneda del reino de Maliorca, pagadera por todas las gentes, sin distinción de estamentos sociales, tanto de la ciudad como de las villas, por considerarse que todos, por acción o por omisión, eran colectivamente responsables de los desmanes cometidos desde la invasión de la ciudad el 2 de agosto. $Y$ en el mismo mes de octubre, se restablecieron los impuestos que gravaban todo lo que se compraba o se vendía o se transfería o se contrataba.

En el entretanto, judíos y conversos se sentían inmersos en un ambiente social de prevención y hostilidad generalizada. Es cierto que en enero de 1393 un bando de Gobernación, reiteró que los judíos estaban bajo el amparo y la salvaguardia del rey, y que el que los dañara en persona o bienes, cualquiera que fuera su condición social, respondería con su cabeza como reo de lesa majestad; y que otro bando, recordó las severas penas imponibles a los que violando lo ordenado entraran en la judería y robaran cosas o provocaran disturbios. A pesar de ello, se sentían desprotegidos por las magistraturas que debían preservarles, por to que rechazados los conversos por los "cristians de natura", por la comunidad de cristianos viejos, procuraron formar una nueva comunidad solidaria.

Los conversos que desde la devastación de la judería, sin estar facultados, designaban portavoces que ejercían oficiosamente como procuradores de sus intereses, constituyeron en 1404 con la venia del rey una cofradía de conversos, embrión de la reconocida en 1410 como cofradía nueva de San Miguel Arcángel, cuya organización por las amplias competencias atribuidas a los «sobreposats», que recuerdan las que antes tenían los secretarios de la aljama judía, aparentaba un trasunto formalmente cristianizado de la aljama de Mallorca. 
Los «sobreposats» presidían y gobernaban la cofradía, estaban facultados para repartir y recaudar tallas (impuestos directos sobre el patrimonio neto del contribuyente) entre los cofrades para satisfacer atenciones de la comunidad y, lo que es más significado, ejercían competencias judiciales en orden a resolver cuestiones leves entre cofrades, según hacían los secretarios de la aljama.

El pago de la cuota social, lo que también es indicativo, en la cofradía de San Miguel Arcángel, se realizaba los viernes y no los sábados, como era lo habitual en los gremios y cofradías, lo cual sugiere que la sabatización, la consideración del sábado como día festivo, como hacían los judíos, era práctica respetada por los conversos; y no es menos reveladora la norma que extendía los beneficios sociales ordenados para los cofrades, a cualquier converso aunque no estuviera asociado o fuera converso forastero, y el hecho de que en las Ordenanzas no se otorga a las festividades religiosas ni a los ejercicios de adoctrinamiento en la fe cristiana, la función principal que tenían en las otras cofradías, constituidas a la mayor honra del santo patrono titular.

En suma, la cofradía de San Miguel Arcángel funcionaba de hecho como una solidariclad, como una comunidad solidaria conocida como «Universitat e comunitat de conversos de Mallorca».

\section{LOS CONVERSOS DE 1435}

La emigración de judíos y de conversos secuela de las perturtaciones de 1391 comportó, como era de esperar, una disminución del tráfico mercantil tanto interior como exterior, ejercido en buena parte por mercaderes judíos; y el descenso del tráfico conllevó la reducción de la recaudación fiscal. La Administración, aunque el personal de los niveles medio y bajo era hostil a judíos y conversos, comprendió la perentoriedad de reactivar la aljama, muy quebrantada tras los trastornos acaecidos, fomentando el asentamiento de judíos en Mallorca y su participación en el proceso económico insular.

En aplicación de dicha política se favoreció en 1394 el establecimiento en Mallorca de un contingente de unos 190 judíos escapados de Portugal, a los que Juan I, a instancia de los emisarios del Consell de Mallorca, otorgó su protección y salvaguardia y los privilegios que tenían los judíos de la aljama de Mallorca, lo que significaba su integración en la aljama de Mallorca, cuyos miembros, aunque eran parte de un colectivo que tenía plena autonomía para administrarse separadamente de la Administración 
cristiana de Mallorca, gozaban además de la condición de ciudadanos de Mallorca, y se beneficiaban de los privilegios y franquicias otorgadas por los reyes a Mallorca, si bien como tales ciudadanos debían acatar las normas generales ordenadas por los jurados y el Consell General de Mallorca y promulgadas por el gobernador de Mallorca, en su condición de otro yo del rey.

Pero la postura de la Administración frente a los judíos, condicionada por el clima de prevención antijudía, continuó vacilante y recelosa. Al efecto, un bando de septiemre de 1401 pretextando que algunos judíos y sarracenos adoptaban actitudes consideradas de desprecio, frente a símbolos como la custodia llevada por sacerdotes para impartir la extremaunción a fieles en peligro inminente de muerte, dispuso que los judíos y sarracenos se arrodillaran devotamente al paso por las calles de la custodia, como se arrodillaban los cristianos, y que los que no quisieran arrodillarse debían retirarse al interior de las casas.

La resolución se razonaba, según solía argumentarse en la cristiandad por lo menos desde el siglo VI, en la errónea consideración doctrinal de que los judios, los moros y los otros infieles, en razón de la sagrada pasión de Jesucristo, quedaron subyugados a servidumbre perpetua respecto a los cristianos, por lo que en los países cristianos, donde se les soportaba, debian abstenerse de ademanes que implicaran injuria, meniosprecio o vergüenza de la fe cristiana.

Desde esa filosofía de intolerancia un tal miser Martí, emisario del Consell General de Mallorca, instó de la reina María, lugarteniente de la Corona de Aragón en ausencia de su esposo Alfonso $V$ el Magnífico, una ordenanza prohibiendo a los judíos habitar en Mallorca, petición que procede entender no en el sentido de expulsar a los judíos sino en el de prohibir que judíos forasteros se establecieran en Mallorca, sin vedarles estancias transitorias. En todo caso, aun en el supuesto de que la ordenanza llegara a promulgarse, como parece, no se aplicó.

El Consell General de Mallorca, en noviembre de 1416, noticioso de que un grupo de judíos del reino de Tremecén, donde eran perseguidos, solicitaba acogida en Mallorca, aprobó la solicitud, «no contrastant lo privilegi obtingut per misser Martí de la senyora reyna que juheus no pusquen habitar en Mallorca». El Consell, facultó a los jurados para urgir de los reyes la concesión de los salvoconductos necesarios y para tomar las medidas adecuadas al establecimiento de dichos judíos, por considerar que su asentamiento en Mallorca sería de «gran profit e utilitat a la cosa publica, axi per la població de aquells com per los grans bens quis diu hic aportaran". 
No se sabe si llegaron a establecerse en Mallorca los judíos de Tremecén, lo que consta es que la aljama, que por lo que se deduce no logró recuperar tras el trauma de 1391 la vitalidad de antaño, se cristianizó colectivamente el año 1435, según se manifiesta en la siguiente petición suplicada, presentada el 10 de marzo de 1436 en Monzón a la reina María por emisarios del Consell General de Mallorca y aprobada por la reina:

«En lo regne de Mallorca, mes divinament que humana, sia stada poch ha extinguida la perfidia judayca, en tal que call ne sinagoga vuy en lo dit regne no ha. Plaçia a vostra excellencia statuir que dequi avant, en lo dit regne, no puxa star ne habitar en lo dit regne pus avant de quinse dies alcun jueu, ne pusca esser call ne sinagoga de jueus, sots pena de confiscació de lurs bens». Resolución de la reina: «Plau a la senyora reyna».

La petición documenta la conversión en 1435 de la aljama judía de Mallorca, y avala las líneas generales de la tradición historiográfica que contempla el trascendental acaecimiento como obra de milagro, aunque don Juan Binimelis, primer cronista del reino de Mallorca, en su Historia de Mallorca, elaborada a fines del siglo XVI, presenta la cristianización no como tradición historiográfica sino como hecho providencial.

Relata Binimelis, que en la semana santa de 1435 cuatro judíos, llevados por un diabólico pensamiento, parodiaron en la persona de un cautivo que se avino a ello la pasión de Jesucristo. Noticioso el obispo Gil Sanchez Muñoz de la parodia, en la que no hubo derramamiento de sangre sino actos simulados, ordenó enseguida, el 27 de abril de 1435, apresar a los cuatro judíos y al sarraceno protagonistas de la imitación burlesca y dispuso la apertura de una indagación procesal.

Luego el obispo, requerido por el lugarteniente del gobernador, que alegaba con razón que los hechos eran competencia de la justicia secular y no de la justicia eclesiástica, entregó a los judíos acusados, a los que se abrió proceso criminal, con resultado de cuatro penas de muerte. Los reos, que eran precisamente los más prestigiosos y respetados rabinos de la judería, inducidos por las reflexiones espirituales de dos sacerdotes teólogos que les atendieron, sorprendentemente, se cristianizaron.

La conversión de los rabinos, determinó que los judíos de la aljama, impresionados, arrastrados por su ejemplo, pidieran en masa el bautismo. "Tanta prisa tenían en ser bautizados - cuenta Binimelis, que escribió su Historia en castellano y en mallorquín-, que cuatro sacerdotes no bastaban para bautizar aquella multitud de judíos... y por cuenta se halló que en dos días se bautizaron más de doscientos". Después el lugarteniente de gobernador, ante la clamorosa petición de ¡Misericordia! de los recién bautizados y de gran número de cristianos viejos, indultó a los cuatro rabinos condenados. 
La cristianización de la totalidad de los judíos de la aljama, es acontecimiento sin paralelo en ninguno de los otros territorios que componían la Corona de Aragón ni en los de la Corona de Castilla, donde las aljamas continuaron activas hasta la aplicación del decreto de expulsión de los judíos en 1492. Con ello se cerraba un ciclo histórico importante, en el que los judíos de Mallorca habían ejercido como motor de la mercadería, base de la estructura económica insular, y como promotores de talleres cartográficos que confeccionaban brújulas y famosas cartas náuticas.

La circunstancia de que llevaran a efecto dichas aportaciones en ambientes sociológicos desalentadores, avala mayormente su mérito y testimonia su mallorquinidad, puesta a prueba en duros trances.

\section{LA COMUNIDAD DE LOS CONVERSOS, A FINES DEL SIGLOXV}

Se cerraba en 1435 un ciclo histórico, el de los judíos de Mallorca, y se proseguía el de sus descendientes, los conversos de Mallorca, receptores de su legado tanto en la mercadería como en la cartografía. Y aunque persistía cierta desconfianza entre cristianos viejos y cristianos nuevos y la convivencia social, sin confraternidad, fuera recelosa, no existía la abierta animosidad de antes, y la Administración comprendía el quehacer de los conversos, que ya no estaban asociados en ninguna cofradía confesional especial, en la estructura económica de Mallorca.

Por ello al conocerse la noticia de que 50 familias de conversos valencianos habían arribado a lbiza con intención, según se decía, de continuar navegación a Sicilia, donde pensaban establecerse, los jurados de Mallorca comisionaron a Juan Massana para proponerles establecerse en Mallorca, prometiéndoles el otorgamiento de la «franquesa de prevere», es decir, la franquicia de impuestos durante los primeros diez años de su asentamiento en Mallorca, pero no consta que los conversos valencianos aceptaran la propuesta.

Los conversos no vivían agrupados, como acaeció desde el siglo XVI, "en las calles de costumbre". A tenor de los datos de la talla recaudada en 1478, la gran mayoría ( 80 por 100) habitaba en la parroquia Santa Eulalia, en especial en las calles de la que fue judería medieval. Los restantes residían en las parroquias San Nicolás (19 por 100), Santa Cruz (11 por 100), San Jaime (1,75 por 100) y San Miguel (1,75 por 100), de manera que entonces los conversos aunque habitaran mayormente $(47,50$ por 100) en lo que fue judería medieval, coexistían con cristianos viejos en todas las parroquias de la ciudad. 
No obran indicios de tensiones entre las corporaciones de menestrales y los conversos. Es cierto que los peleteros reformaron sus estatutos en 1435, año de la cristianización de la aljama de Mallorca, para prohibir que los maestros peleteros enseñaran el oficio a algún converso o a hijos o nietos de conversos, pero la norma se adoptó más por motivaciones laborales (frenar la competencia de los numerosos peleteros conversos), que por intenciones confesionales y fue una excepción en el comportamiento general de los menestrales.

Los tejedores de lino no modificaron los estatutos de 1384 que admitían a los judeoconversos ( Ningún maestro puede enseñar el oficio a judío o hijo de judío si no se hace cristiano"), los estatutos del gremio de manteros de 1391, confirmados en 1467, disponían que «los judeoconversos aunque sean del linaje de infieles pueden ser admitidos en el oficio», y los del gremio de tejedores de lana reglamentaban que «los maestros que tengan aprendiz cristiano de naturaleza o converso pagarán (en la caja del gremio) dos dineros todos los sábados».

En el gremio de los corredores de oreja la mayoría de agremiados era conversa, y en los estatutos de 1485 , si bien se precisa que ningún converso podrá ser elegido rector del gremio, se indica que de los tres pronombres de la Junta de Gobierno, uno tenía que ser converso; y a tenor de los estatutos de 1493 del gremio de los jaboneros, de mayoría conversa, la Junta de Gobierno la integraban dos «sobreposats», uno converso y otro de naturaleza cristiana, y dos «proomens», uno de naturaleza cristiana y otro converso.

En las revisiones de los estatutos gremiales promulgados en la época de Fernando el Católico, etapa de gran dinamismo corporativo en toda la Monarquía española, no se introducen discriminaciones frente a los conversos, ni tampoco se adoptan en las normas estatutarias de las nuevas corporaciones gremiales facultadas en Mallorca (boneteros 1483, pintores 1488 , cinteros-correros-pergamineros 1490 , aluderos 1499 , hortelanos 1502, colcheros y colchoneros 1513).

En el último cuarto del siglo $x v$, había conversos en casi todas las ramas de la economía, sobre todo en las actividades relacionadas con el corretaje mercantil, la compraventa y el manejo de dineros, y en quehaceres en los que la agilidad mental y la habilidad manual contaba más que el esfuerzo físico, porque requerían más maña que fuerza. En una ciudad de unas 15.000 almas como la ciudad de Mallorca, el volumen de las referencias constadas sobre actividades de conversos es significativa. Los conversos dominaban en el corretaje mercantil (66 corredores) y el pequeño comercio interior (botigueros 24 , tenderos 20 , merceros 6 , especie- 
ros 5 , revendedores 3 , cinteros 2 , candeleros 2 , cereros 2 ), y su presencia era importante en el comercio (60 mercaderes), en la platería (18 plateros) y en la confección de jabones (29 jaboneros).

Era principal la participación de conversos en la artesanía de la piel (pellejeros 31, zapateros 25, curtidores 6), en la confección textil (sastres 88 , calceteros 26 , juboneros 2 , boneteros 2) y en la artesanía textil (tejedores 29, tintoreros 16, pelaires 4 , tundidores 2, pespuntadores 2); y de cierta consideración en los trabajos de la madera (basteros 5 , cofreros 5 , carpinteros 3 , torneros 2 , silleros 2 ), y de menor entidad en la hostalería (hostaleros 2) y en la alimentación (horneros 3, confiteros 2).

Había conversos entre los subalternos de la Administración (capdeguaytas o alguaciles 4 , portadores de letras 7 ), pero no consta que asumieran funciones públicas de representación política de la comunidad (jurados, consejeros, clavarios, mostassafs, oidores de cuentas), ni de ejercicio de poder jurisdiccional (bailes, veguers), ni de recaudación de impuestos, actividades ejercidas por cristianos viejos, aunque legalmente algunos podían ejercerlo, pues la inhabilitación para ocupar oficios públicos y de honra a tenor de la pragmática de 20 de septiembre de 1501, promulgada por los Reyes Católicos, sólo afectaba a la primera generación por línea femenina y a la segunda generación por línea masculina.

Los conversos ejercían profesiones liberales. En el escalafón de notarios, actividad vedada a los conversos en algunas ciudades como Barcelona, había cinco notarios ejercientes que probablemente no eran los únicos, y por lo menos dos abogados, dos médicos de prestigio (Johan Alexandre Adret y mestre Garriga), dos cirujanos, diez barberos y un boticario. La participación de conversos en labores agrarias era de orden excepcional (sólo dos labradores, un bracero, un carbonero), sin que conste su participación en otras actividades laborales (calafates, tragineros, herreros, pintores, albañiles, canteros, etc.)

Nada se oponía en el reino de Mallorca en la época de Fernando el Católico, a que un converso fuera sacerdote o entrara en religión, pero no conozco datos sobre sacerdotes o religiosos conversos. El canónigo de Mallorca Pedro Monforte, destituido en 1486 por incurrir en herejía y apostasía, según se indica en una carta de Fernando el Católico, no era mallorquín ni hay noticia de que se le procesara en Mallorca.

Los datos de la talla de 1478 manifiestan que el primer contribuyente de la ciudad, por tener el patrimonio más cuantioso, era la conversa Esclaramunda Pardo y Martí (cuota de contribución 45 libras moneda de Mallorca), y entre los mayores contribuyentes figuran la herencia del caballero mosén Perol Pardo, descendiente de conversos (cuota 20 libras), y 
el mercader converso Joan Vidal (cuota 18 libras), pero la gran mayoría de los conversos a juzgar por la cuota que pagaron, proporcional a la valoración del patrimonio neto que tenían descontadas las cargas, eran medianos (cuota entre 1 y 6 libras) y sobre todo pequeños contribuyentes (cuota de menos de 1 libra), si bien en las instrucciones que encomendó el Consell General de Mallorca a Juan Dusay, emisario acreditado ante el Consejo Supremo de la Inquisición, se alega que los conversos poseían para su servicio o para negociar con ellos más de 400 cautivos, muchos de ellos cristianos.

La citada Esclaramunda Pardo contrajo matrimonio con el opulento mercader Joan Beltrán, y la hija de ambos, Beatriz, desposó primero con el gentilhombre Joan Palou y luego con el doncel Macià Safortesa, y el caballero Perot Palou y Beltrán, señor del Vall de Canet, enlazó con Aldonsa de Torrella hija del doncel Joanot de Torrella. Tales enlaces de conversos con mercaderes y caballeros cristianos viejos, aunque excepcionales, porque lo más normal era el matrimonio entre conversos, no parece que motivaran en el siglo $x V$ rechazo social, mientras se considerara al converso buen cristiano y súbdito leal.

\section{LA NUEVA INQUISICIÓN}

En el reino de Mallorca, como en otros reinos de España, la Inquisición medieval fue poco activa en el siglo XV. E1 1407 condenó a muerte como judaizante al converso Juan de Galiana, cristianizaclo en 1391. Luego transcurrió un largo período de quietud inquisitorial hasta que en 1478 reconcilió con la Iglesia a dos matrimonios del linaje Gener, también descendientes de cristianizados en 1391, después en 1482 reconcilió a Joan de Tagamanent y en 1485 a otros tres conversos.

El año 1478 fue de insólita actividad inquisitorial: ocho reconciliaciones ( 3 hombres y 5 mujeres). Era el final, el canto del cisne de la Inquisición medieval en Mallorca, que salía de su letargo precisamente cuando era inmediata la publicación de la bula de Sixto IV, que estableció el mismo año 1478 la nueva Inquisición.

En Mallorca se recibian noticias sobre la inquietud que generaba, sobre todo entre los conversos, las actuaciones de la nueva Inquisición en las ciudades donde se establecía, y probablemente los conversos mallorquines estarían preocupados, porque la instauración del Tribunal en 1484 en Zaragoza y en Valencia y en 1486 en Barcelona, presagiaba su próxima extensión a Mallorca. 
Los jurados del reino, cuando en julio de 1487 conocieron la resolución de extender a Mallorca la Inquisición reformada, comunicaron enseguida sus reparos a Fernando el Católico, pues estaban convencidos de que provocaría una huida de conversos que agravaría la situación de despoblación de la isla, y consideraban que mantener en el proceso inquisitorial secreta la identidad de los testigos, motivaría falsos testimonios y delaciones de mala fe. «Els principals del regne -advirtieron al rey aludiendo a los linajes de conversos de mayor solvencia económica y social- tenen gran temor y espant»

El 17 de agosto de 1487, se recibió en la Procuración Real una carta del rey notificando que fray Tomás de Torquemada, inquisidor general, en aplicación de las facultades conferidas por Inocencio VIII en bula de 6 de febreso de 1486, cesaba al inquisidor de la antigua Inquisición Guillem Cassellas, y en julio de 1488 desembarcaron en el muelle de la ciudad de Mallorca los inquisidores de la Inquisición reformada fray Sancho Martín y fray Pedro Pérez de Munegreba. Algún tiempo después, en la sesión celebrada por el Consell General de Mallorca el 2 de octubre de 1495, el jurado Juan Aguiló manifestó: "En negun dels regnes de Sa Magestat, sia stada la Sancta Inquisiciò venerada e pacificament e ab molta obediencia los actes de quella executats, millor que en aquest regne».

En el reino de Mallorca, en efecto, la instauración de la Inquisición nueva motivó expectación y ansiedad, pero no incidencias como las acaecidas en Sevilla, en Teruel, en Barcelona y entre otras ciudades en Zaragoza, donde un grupo de judeoconversos asesinó en la Seo al inquisidor Pedro de Arbués la noche del 13 de septiembre de 1485, provocando una violenta reacción popular, que estuvo a punto de ocasionar una matanza de judíos y de conversos. Es posible que ante la inutilidad de la resistencia presentada en otros lugares, la sociedad de Mallorca, como en otras coyunturas históricas, se dejara llevar por la pasividad y el conformismo en vez de empeñar batallas que consideraba perdidas de antemano.

En el reino de Mallorca sólo se manifestaron ciertas tensiones de tono menor, pero no entre masas populares y la Inquisición o entre conversos y la Inquisición, relacionadas con comportamientos de los inquisidores, que la Administración de Mallorca entendía abusivas y en contradicción con las libertades, fueros y privilegios del reino. Eran agravios relacionados con la jurisdicción (por ejemplo, la avocación por los inquisidores de causas que competían a jueces ordinarios), la economía (por ejemplo, iniciativas de los inquisidores entendidas como perturbadoras del comercio), la hacienda (por ejemplo, la inmunidad fiscal que pretendían funcionarios lai- 
cos de la Inquisición), y de orden público (por ejemplo, la designación como familiares de la Inquisición de individuos de mala vida).

Tales tensiones no generaron un clima social anti-Inquisición, y la Administración no cuestionaba la existencia en Mallorca del Santo Oficio sino ciertos procedimientos del Santo Oficio. Los conversos, rechazaban la Inquisición, pero los cristianos viejos, que venían a representar el 95 por 100 de la población insular, en su mayoría respaldaban la Inquisición y prestaban asistencia popular al Tribunal, que ateniéndose a las Instrucciones del Consejo Supremo de la Inquisición de 1484 (Primeras Instrucciones) y a las Instrucciones de enero de 1485 (Segundas Instrucciones), comunes a todos los tribunales de la Monarquía española, publicaron en agosto de 1488 un Primer Edicto de Gracia, para que los cristianos incursos en herejía o apostasía manifestaran y confesaran sus errores.

Se acogieron voluntariamente al Primer Edicto 424 conversos, de los cuales 337 dentro del plazo señalado de un mes y 87 fuera de plazo, por concesión graciosa del inquisidor Juan Ramón. La reconciliación reintegraba al penitenciado al seno de la Iglesia, a la comunión de los fieles, y los acogidos a dicho Primer Edicto, sancionados con penas espirituales y aflictivas, para evitar la confiscación de sus patrimonios, convinieron con el receptor del Tribunal el pago de una composición económica, sustitutiva de la confiscación, de 10.560 libras moneda de Mallorca pagadera a plazos, a repartir entre todos los penitentes en proporción a la valoración del patrimonio líquido de cada uno de los reconciliados.

Tres años después, en julio de 1491, el inquisidor fray Juan de Astorga promulgó, probablemente a súplica de los jurados, un Segundo Edicto de Gracia, al que se acogieron 416 penitentes, de los cuales 140 reconciliados por primera vez y 276 relapsos, es decir, reincidentes en prácticas judaicas tras ser reconciliados en el Primer Edicto de Gracia o por el procedimiento ordinario de reconciliación, más riguroso en las penas aplicadas. A estos penitentes relapsos les correspondían penas muy severas, pero acogiéndose al Segundo Edicto de Gracia saldaron la relapsía con sanciones espirituales y aflictivas y contribuyendo al pago de una sanción económica sustitutiva de la confiscación de bienes, de 4.800 libras, pagadera entre todos los 416 penitenciados en proporción a su patrimonio.

El que la segunda composición a pagar a la recepta de la Inquisición fuera más baja que la primera cuando los cargos, por la incidencia de las relapsías, eran más graves es indicativo de que los inquisidores tomaron en consideración la disminución patrimonial de los penitenciados y su situación de precariedad económica, afectados algunos por el pago de la 
primera composición, y todos afligidos y empobrecidos al no poder realizar con normalidad sus habituales quehaceres y negocios, en un ambiente social de incertidumbre, ansiedad y pánico.

Los extractos continuados en las Misceláneas Pascual (Archivo del Reino de Mallorca), de subastas instadas por la Inquisición de propiedades de los conversos en los años 1489 a 1506, ratifican la apreciación de que los patrimonios de la gran mayoría de los conversos, constituidos por modestas viviendas y a lo más algún pequeño huerto a extramuros de la ciudad, eran de escasa cuantía. A excepción de una viña de Pereta Gual, lindante con el camino de Inca, que rentaba anualmente unas 77 libras, 0 un huerto y viñedo con vivienda y lagar que Joan Arnau poseía en el camino de Sóller, subastado por 191 libras, los demás pequeños huertos se subastaban a precios entre 4 y 40 libras.

Pocas viviendas alcanzaron precios altos al subastarlas. La casa del rico mercader Joan Vidal la compró el mercader Martín Bonaparte en 1490 por 923 libras, la del médico Joan Alexandre Adret la adquirió el mercader Joan Liula por 781 libras, y algunas otras viviendas se adjudicaron o se transfirieron a precios entre 100 y 400 libras, pero la gran mayoría de casas fueron transferidas a precios convenidos oscilantes entre 10 y 80 libras.

La gran mayoría de las propiedades, tanto huertos como casas, fueron transferidas y no se subastaron, porque el receptor de la Inquisición sólo las sacaba a subasta cuando no se avenía con el propietario reconciliado o con algún familiar suyo sobre el precio.

En noviembre de 1492, los jurados de Mallorca informaron a Fernando el Católico sobre la situación de extrema penuria de muchos reconciliados. «Stan posats - advertían al rey- en la maior necessitat que crehem que altres vasals e subdits no la poden tenir major», y le pedían al rey que les otorgara moratoria del último plazo que importaba 1.600 libras, de la segunda composición de 4.800 libras, plazo que vencía a fines de 1492; y saliendo al paso de las objeciones de los que en Mallorca decían que los reconciliados sí que podían pagar, los jurados comunicaron al rey en enero de 1493, que de exigirse lo que se adeudaba muchos de los reconciliados quedarían en la calle, sin nada.

La situación apurada de buena parte de los conversos, no resultaba sólo del pago de las composiciones, que importaron un total de 15.360 libras, cantidad no equiparable a la multa de 95.000 libras impuesta en 1315 por el rey Sancho de Mallorca a la aljama para conmutar la sentencia de confiscación de sus patrimonios por "ciertos crímenes cometidos", ni la sanción de 90.000 libras dictada por la reina Violante en 1392 por la de- 
vastación de la judería de Mallorca, pagadera por todos los cristianos. Aparte de la incidencia de las composiciones, el estado de precariedad resultaba de dificultades cotidianas que entorpecían el ejercicio de sus oficios, y del trauma físico y moral que comportaban los procesos.

La circunstancia de que 564 conversos, acatando los Edictos de Gracia, solicitaran de 1488 a 1491 la reconciliación, manifiesta el ambiente de desmoralización y de pánico que cundía entre los conversos, aunque muchos persistieran en sus creencias o mantuvieran costumbres y prácticas que la Inquisición consideraba judaicas. No obstante, no era habitual que, como acaeció en Mallorca, el 63 por 100 de los reconciliados en el primer edicto cayeran de inmediato en relapsía, y se acogieran al segundo edicto para reconciliarse por segunda vez, ni que el 8 por 100 de los reconciliados fueran condenados a muerte, en procesos posteriores a la reconciliación, como judaizantes convictos y confesos, lo que es indicativo de la fidelidad de muchos conversos a sus creencias, tradiciones y costumbres.

De 1488 a 1516, época de Fernando el Católico, durante los primeros 28 años de la actividad del Santo Oficio, además de reconciliar a los penintenciados que se acogieron a los Edictos de Gracia, la Inquisición reconcilió en procesos ordinarios a 181 penitentes y relajó al brazo secular a 457 sentenciados a muerte, de los cuales 2 en huesos (uno fallecido durante el proceso y otro procesado después de fallecer), 82 ejecutados en persona y 373 procesados en ausencia y ejecutados en estatua, es decir, el 59 por 100 del total de los 638 procesados por la Inquisición en la citada época lograron ponerse a salvo, huyendo de Mallorca antes de ser procesados.

La indagación inquisitorial no afectó a todos los conversos de Mallorca sino a los que, tras los edictos de gracia, fueron delatados como judaizantes por más de un testigo y a los procesados de oficio, por mediar sospechas de que practicaban ritos y ceremonias de la ley judaica. La afirmación de los jurados de Mallorca, comunicada en febrero de 1492 al rey, de «tan solament resten dos casadas de conversos ultra aquells que segons se diu han obtesa gracia -acogiéndose a los edictos- de Vostra Magestat», no procede entenderla en el sentido de que entonces todos los conversos, menos "dos casades", estaban ya reconciliados, sino en la acepción de que entre los conversos de mayor prestigio social y solvencia económica, habían sido reconciliados todos menos dos familias, una la de Perot Pardo y otra no identificada que acaso podía ser la de los Cavalleria, ricos mercaderes procedentes de Aragón y de notoria ascendencia conversa.

Los reconciliados y relajados en la época de Fernado el Católico son de 259 linajes, en la acepción de apellidos, eran residentes en la ciudad 
excepto unos pocos, y aunque había cinco valencianos (uno de Valencia, dos de Alicante y dos de Orihuela), cuatro catalanes (uno de Cataluña, otro de Barcelona, otro de Tarragona y otro de Gerona), dos portugueses, un ibicenco y un menorquín, y algunos se apellidaban Aragonés (1), Burgos (8), Castellano (1), Castilla (1), Díaz (3), García (1), López (2), Lozano (4), Martínez (2), Navarro (7), Rodríguez (2), Segovia (2) o Sevilla (3), en su gran mayoría eran naturales de Mallorca o naturalizados en Mallorca.

\section{PARENTESIS EN LA REPRESIÓN INQUISITORIAL}

Tras el primer período de actividad inquisitorial, el de mayor actividad en especial de 1488 a 1493, la actuación represiva del Santo Oficio, como era de esperar, bajó sensiblemente. No obstante, de 1517 a 1544 se reconciliaron 57 penitentes, 12 fueron ejecutados en persona y 56 procesados en ausencia y ejecutados en estatua. $Y$ tras el auto de fe celebrado en 1544 para reconciliar a un solo judaizante, la Inquisición entró en una larga fase inactiva.

Larga fase inactiva respecto a conversos presuntos judaizantes, pero no respecto a otros conceptos confesionales o de costumbres que el Santo Oficio tenía como delictuales, porque si bien de 1545 a 1673, es decir, durante 128 años, no consta que la Inquisición reconciliara o relajara por judaizar a ningún judeoconverso, el Tribunal que permanecía operante, vigilante, reconcilió un total de 112 penitentes, de los cuales 81 por apóstatas mahometanos, 12 por herejes luteranos y 9 por brujería y hechicería, y relajó en persona a 2 procesados y a otros 4 , procesados en ausencia los ejecutó en estatua.

Muy luego, en 1673, en circunstancias confusas fueron apresados unos judíos que navegaban de Argel a Liorna, a bordo de un barco patroneado por un marino francés que hizo escala en la ciudad de Mallorca. Como en las diligencias procesales se acreditó que los judíos apresados no eran judaizantes sino judíos de nacimiento, nunca bautizados, la Inquisición los puso en libertad por no ser de su jurisdicción ni competencia, excepto a uno llamado Alonso en el que concurrían circunstancias especiales.

Alonso, tras un largo proceso, fue relajado en persona en auto de fe celebrado el 13 de enero de 1675, en el que también fueron relajados en estatua 6 judaizantes portugueses (Lázaro y Gaspar Rodríguez y Antonio Maldonado y sus esposas), procesados en ausencia. Alonso, joven de 16 años, natural de Madrid, de padres judíos conversos, estaba bautizado y al 
rechazar con entereza reiteradamente abjurar de sus creencias, el Santo Oficio lo sentenció a muerte quemado vivo por judaizante obstinado y pertinaz. Y se supo que Pedro Onofre Cortés alias "Moxina", vecino de la calle del Sagell, había comentado: «Lopés ha muerto sirviendo a su Dios y quien muere sirviéndole seguramente será coronado en el cielo»

¿Cómo entender la prolongada pasividad del Santo Oficio respecto a los descendientes mallorquines de judeoconversos? Ángela Selke considera como factores de incidencia, «la corrupción de algunos ministros que permitían a los de la calle comprar a precio elevado su seguridad colectiva», y asimismo "los constantes conflictos de competencia entre el Santo Oficio y los tribunales eclesiásticos diocesanos». Baruch Braunstein, ante lo que denomina «época de atrofia de la Inquisición», se pregunta si «quizá el poder de la nación judía era bastante fuerte para influir, con propinas a los inquisidores 0 a sus amigos, incluso en providencias del Consejo Supremo de la Inquisición", providencias que según piensa entorpecían, retardándolas, diligencias de la Inquisición de Mallorca.

La cuestión es compleja. En la sociedad mallorquina, que tendía en los siglos XVI y XVII a endurecerse y a incrementar su intolerancia, sometida sobre todo en los tramos sociales superiores a un proceso señorializador que repercutía en todio el tejido social, la frustación de la revuelta del campesinado de las villas foráneas de 1450 a 1453 y de la revolución de los agermanados de 1520 a 1523 , de consuno con otros factores políticos y socioeconómicos, contribuyó a mermar el peso del sindicato de las villas foráneas y de las corporaciones de menestrales, al tiempo que coadyuvó a potenciar la oligarquía urbana, el caballerato y la nobleza, comprometidos en poderosas banderías rivales, que ejercían frente a las entidades sociales y al aparato de la Administración (Lugartenencia real, Procuración real, Juraduría, Consejo General, Real Audiencia, Cabildo diocesano, Inquisición), como poderes fácticas, que recurriendo a eficaces procedimientos mafiosos para intimidar y ajustar cuentas, en un clima social de profunda atonía y amedrentamiento generalizado, imponían a su aire la ley del más fuerte.

La Inquisición, como institución, procuraba estar al margen de las banderías, pero como sus familiares, elementos con frecuencia conflictivos, solían ser activos componentes de las mismas, las salpicaduras de los intereses creados o de las pugnas banderizas, en ocasiones eran inevitables. «Si estos negocios no se aprietan y no se castigan - notificó el inquisidor Miguel Gual en comunicado del 23 de junio de 1564 al Consejo Supremo de la Inquisición - vendrán a perder el respeto, que no tendrán cuenta con los del Santo Oficio ni con nadie, porque ya se atreven a herir 
a los familiares y a tomarles los caballos». Mediaba falta de respeto a la Inquisición, y de sus archivos desaparecían expedientes comprometedores. «Habiendo sido reconciliada años ha por judía Esclaramunda, por ser rica, casó sus hijas con los más ricos y principales de esta tierra, y haciendo yo una Memoria y buscando el proceso - refiere el inquisidor Félix Hevia de Oviedo en informe al Consejo Supremo de 5 de octubre de 1580 - no se halla, y algunas personas dicen que han visto el hábito -el sambenito- de la susodicha con los demás en la iglesia de San Fracisco, y tampoco se halla».

Los dos únicos inquisidores mallorquines de la Inquisición de Mallorca en el siglo XVI, Nicolás Montayans y Berard de 1541 a 1563 y su sucesor Miguel Gual de 1564, eran de ascendencia conversa, y el doctor Hugo Berard, que ejerció en Mallorca los oficios de abogado fiscal, procurador real, auditor de la Real Audiencia, lugarteniente del virrey y durante 18 años consultor del Tribunal de la Inquisición, era nieto de Beatriz Beltrán reconciliada el 4 de septiembre de 1490 y sobrina de Pereta Gual, esposa del honorable Martín Gual, relajada en persona el 37 de julio de 1489.

La destitución como consultor del doctor Berard y luego las presiones para que se designara consultor al doctor Jorge Fortesa, también de ascendencia conversa, motivaron la apertura de una indagación, sobre la cual el inquisidor Francisco de Esquivel advirtió en 1598 al Consejo Supremo: «Por ser los interesados en este negocio (limpiesa de sangre) de los poderosos del reino, podía resultar alguna inquietud a esta Inquisición... Y si este negocio (en el sentido de investigación) no estuviera comenzado antes de venir aquí, hiciera instancia muy grande suplicando a Vuestra Señoría (el inquisidor general) que no se pusiera en plática». La investigación se paró. «De lo que Vuestra Señoría manda - manifiesta después el inquisidor Esquivel- que no se hagan informaciones sobre la limpieza (de sangre), estoy advertido y se hará puntualmente lo que Vuestra Señoría manda».

Los desafueros de las banderías apenas suscitaban alarma social manifiesta, habituadas las gentes a asumir calladamente lo «anormal» como «normal», que es lo que suele suceder en sociedades flageladas por el terrorismo, como se evidencia en experiencias actuales. Mientras cundía la intolerancia y la violencia, se generalizaba la postura, descomprometida, de «no veo, no siento, no oigo, no hablo» o bien la de «no pasa nada y si pasa, no importa». Algunas notificaciones de los inquisidores son muy expresivas. «Son más de 400 muertes las que se han cometido -informaba el inquisidor Juan de Godoy, en 1519 al inquisidor general- después que estoy aquí (llevaba dos años y medio en el cargo) con arcabuces y pistolas, y son tan 
ciertas las venganzas que no hay quien tenga la vida segura. Los principales de estos bandos son cepas y cabezas de tantos sarmientos, que cualquier paso que da la justicia se encuentra con ellos. La potencia suya es toda la que esta ciudad y reino tiene, así para cosechar los testigos con dádivas y matallos si son contrarios, cosa para acá muy fácil y ordinaria».

«Son tan frecuentes los homicidios en este reyno de algunos años a esta parte -informaba en 1634 el Cabildo diocesano al rey-, que comúnmente se tiene por maravilla pasar un sólo día sin haberse cometido delictos de esta qualidad (homicidios); y aún más que la frecuencia, es escandalosa la atrocidad con que se cometen, pues se motivan los más de estos homicidios de injurias leves. Nadie se siente seguro en ninguna parte, y los robos y violencias han pasado de tal manera los límites de la disolución que ni en los caminos el pasajero ni en las casas los vecinos tienen seguras las vidas, honras y haciendas".

En ambiente tan peligroso y conflictivo, la Inquisición de Mallorca procuraba mantenerse alertada. En 1715, se remitió al Consejo Supremo la testificación voluntaria de Juana Forteza, viuda del platero Valleriola, denunciando ciertas prácticas de su hermano y de su familia, con los que convivía en la calle Bolsería, que "ella sin saberlo cierto... sospechaba serían de la ley de Moisés». No consta que el Consejo Supremo adoptara resoluciones. El expediente quedó archivado.

En 1613, pese a las inquietudes y desasosiegos que suscitaba, el inquisidor, con la venia del Consejo Supremo, renovó los sambenitos, expuestos a la vergüenza pública, desde el establecimiento de la Inquisición reformada, como en otras ciudades de la Monarquía española, en el claustro del convento de San Francisco de la ciudad de Mallorca, y en 1619 se añadieron otros sambenitos que faltaban. Luego, el inquisidor Matías Escalso Acedo, publicó y difundió ampliamente, en 1624, un edicto en el que, para conocimiento de los cristianos viejos, y a efectos de denuncia, relacionaba los signos externos denotantes de prácticas judaicas, y se ofertaba la reconciliación con la Iglesia a los que solicitaran misericordia y confesaran sus errores en el término de un mes. Pero el plazo transcurrió sin que nadie formulara denuncias o suplicara misericordia. ¿También en este punto era efectiva la ley del silencio? Pudiera ser.

\section{LA COMUNIDAD CONVERSA MEDIADO EL SIGLO XVII}

Los apellidos de los contribuyentes de la ciudad de Mallorca relacionados en la talla recaudada por la Administración el año 1636, evidencian 
que la gran mayoría de los descendientes de los centenares de conversos reconciliados o relajados en la represión inquisitorial, habían emigrado de Mallorca a tierras más tolerantes, lo que está probado respecto a más de 400 conversos procesados en ausencia y relajados en estatua; o ya estaban plenamente integrados en la sociedad de cristianos viejos y de ello se tenía conocimiento, o eran de familias extinguidas en el decurso del tiempo. El hecho es que mediado el siglo XVII, los dos centenares largos de apellidos de procesados por presunta judaización se habían reducido a una quincena de apellidos de vecinos, residentes en su mayoría en el núcleo urbano central de la parroquia Santa Eulalia. Eran los quince apellidos siguientes: Aguiló, Bonnin, Cortés, Forteza, Fuster, Martí, Miró, Picó, Piña, Pomar, Segura, Tarongí, Valentí, Valleriola y Valls.

En su mayoría $(55,63$ por 100$)$ residían en la parroquía Santa Eulalia, pero no como antes en calles de la antigua judería sino instalados en pleno centro comercial urbano, en especial en tres calles: Bolsería, Sagell (actual Jaime II) y Argentería, y en particular en las manzanas nombradas de Antoni Amer, de mosèn Valentí y de Gabriel Sampol, por lo que ya entoces, en 1636, en el lenguaje coloquial de los cristianos viejos se les conocía como «des carrer del Sagell» o «des Carrer». Otro núcleo denso (40 por 100) habitaba en las manzanas Monges de la Misericordia (actual calle Monjas) y de Mateu Font (actual calle San Bartolomé), ambas colindantes con la calle del Sagell, de manera que ambos núcleos $(95,63$ por 100) conformaban la barriada conversa. Los restantes, muy pocos, residían en las parroquías San Jaime (3,75 por 100$)$ y San Miguel $(0,63$ por 100$)$.

Sólo participaban en la vida política y accedían al ejercicio de oficios de la Administración, los descendientes de conversos ricos que al matrimoniar con cristianos viejos, por lo general de familias venidas a menos, se integraban en estamentos acomodados de la sociedad. A tales descendientes, los "des Carrer» les apodaban "calatravos", apelativo derivado de la Calatrava barrio marginal -el de curtidores- de la judería medieval. Los matrimonios mixtos, mal apreciados por ambas partes, no eran frecuentes pero se celebraban, como el contraído en 1635 entre el negociante acomodado Francesch Bonnín, y Bárbara Bover, hija del honorable Joan Baptista Bover, cuyo primer vástago, nacido en 1637, fue bautizado con los nombres Juan, Baptista, Gregori, apadrinado por el honorable señor Domingo Belloto y la señora Beatriu Socias, los dos de distinguido abolengo. Pero lo corriente, como antes, eran las uniones entre chuetas de similar nivel económico y rango social, uniones por lo general endogámicas, que requerían previas y costosas - por el precio- dispensas de parentesco. 
No había, por lo que consta, médicos ni abogados chuetas como los había antes de instaurarse la inquisición renovada, ni ejercían profesiones liberales salvo algún notario, ni dedicaciones a oficios mecánicos pesados como herreros, carpinteros, albañiles o tragineros, ni a las labores del campo. Los chuetas, de mentalidades conservadoras, seguian afectos a los oficios de sus ascendientes del siglo $\mathrm{xv}$, prioritariamente a actividades comerciales $(41,67$ por 100$)$, como botigueros (27 por 100), marchantes $(6,25$ por 100$)$, negociantes $(2,08$ por 100$)$; y a confecciones textiles y de la piel, como calceteros (16,67 por 100), terciopeleros (14,60 por 100), pelaires $(2,07$ por 100$)$, pasamaneros $(2,07$ por 100$)$ y zapateros $(4,17$ por $100)$; era importante su participación en platería (plateros, 12,50 por 100), y sólo discreta en hornería $(6,25$ por 100), y aunque no obren datos entiendo que tenían peso en sedería, especiería, tejeduría, cerería, sastrería y jabonería. No parece que practicaran la usura, por sorprendente que pueda parecer, e invertían poco por entonces, mediado el siglo XVII, en deuda pública de la comunidad de Mallorca ni en deuda municipal de las villas foráneas sino, preferentemente, en préstamos y censos a particulares escriturados notarialmente, a intereses legales corrientes (del 3 al 7 por 100).

La represión inquisitorial contribuyó a encrespar la postura anticonversos de algunas corporaciones de menestrales como los barberos-cirujanos, confiteros, cereros, especieros y sederos, que reformaron sus estatutos en el curso del siglo XvI para vedar a los descendientes de conversos el ingreso en sus gremios, sin que ello planteara a dichos descendientes mayores problemas, pues es presumible que continuaron ejerciendo sus actividades en régimen de economía subterránea, al margen de los gremios.

Los datos continuados en el registro de la talla recaudada en 1636 para pagar gastos generales de la Administración, que gravó los patrimonios netos de los contribuyentes en un 0,025 por 100 de su importe, permiten una aproximación al conocimiento de la estructura patrimonial de la comunidad conversa mediado el siglo XVII. De los 173 contribuyentes conversos relacionados en la talla, el 60 por 100 son clasificables como pequeños contribuyentes (patrimonio de 1 a 499 libras), el 32 por 100 como contribuyentes medianos (patrimonio de 500 a 4.999 libras), el 7 por 100 como grandes contribuyentes (patrimonio de 5.000 a 19.999 libras) y el 1 por 100 como mayores contribuyentes (patrimonio de más de 20.000 libras).

Mediado el siglo XVII la estructura patrimonial de la comunidad conversa de Mallorca era una estructura equilibrada, con una base mayoritaria pero no abrumadora de pequeños patrimonios, una masa troncal de patri- 
monios medianos y una cúspide significada de patrimonios grandes. Tal perfil patrimonial es indicativo de que por entonces, aunque la represión inquisitorial hubiera contribuido a encrespar las relaciones con los cristianos viejos y el peso demográfico de los conversos hubiese disminuido drásticamente (en el último cuarto del siglo xv había más de mil conversos), la comunidad conversa tenía más cohesión, estaba mejor organizada, patrimonialmente era más acomodada y pienso que más próspera, mucho más próspera, que la del último cuarto del siglo XV.

Es cierto que el 13 por 100 de los contribuyentes conversos, con patrimonios de 50 libras o de menos de 50 libras y una contribución fiscal mínima de 3 dineros, tenían que estar casi inmersos en la pobreza, y que podía haber conversos no continuados en la talla, porque al no tener nada no contribuían, pero la comunidad, llevada de arraigados sentimientos solidarios y benéficos, protegía eficazmente, calladamente, con prestaciones personales voluntarias y cuestaciones comunitarias destinadas a socorrer familias en apuros, a cuidar enfermos desatendidos o faltos de recursos, y a atender ancianos desvalidos o desamparados.

Algunos cristianos viejos afirmaban en testificaciones al Santo Oficio, que los conversos se tenían "por mexores" y que se consideraban superiores a los demás cristianos. Pudiera ser. En una sociedad como la maIlorquina del siglo XVI y XVII, conmocionada por las rivalidades de las banderías oligárquicas-señoriales, la inseguridad generalizada y la violencia incontrolada y presa del escepticismo, de la pasividad y de la insolidaridad, la comunidad conversa venía a ser, en el bronco entorno, como un remanso de paciente y abnegada laboriosidad.

Argumentaban otros testigos a fines del siglo XVII, que aunque los conversos frecuentaran iglesias, santificaran domingos y festividades y asistieran puntualmente a procesiones y sermones con devoción, era religiosidad engañosa porque judaizaban por lo que, en frase del padre Garau, "siendo malos católicos tampoco eran buenos judíos". Tales consideraciones son demasiado generalizadoras. Había, sin duda, conversos que judaizaban y muchos otros que en su vida cotidiana se evidenciaban católicos y, puestos en trance de muerte, a veces, disponían se les amortajara en hábito religioso y ordenaban celebrar misas de réquiem y muchas misas rezadas; y ello, aunque conservaran por atavismo, sin intención ni contenido confesional, usos de hechura judaica, ajenos a su sentir religioso, sin que por ello se suscitaran en otros lugares de España, sospechas de judaizar como se sospechaba en Mallorca, usos que en nuestros días continúan todavía practicándose en tierras de Ávila, en La Moraña, por ejemplo. 


\section{LAS «COMPLICIDADES»DE 1679 Y 1691}

Cuando el joven judaizante madrileño Alonso Lopes fue quemado vivo como judío obstinado y recalcitrante, dicho en lenguaje inquisitorial, el 13 de julio de 1675, en el quemadero acondicionado extramuros de la puerta de Jesús, en presencia de multitudes, de miles de personas al decir de testigos coetáneos, llegadas de los confines de Mallorca ávidas de curiosidad, se ignoraba, nadie sabía, que ya obraba en el Consejo Supremo de la Inquisición el extenso informe acusatorio y el denso atestado diligenciado sobre presuntas observancias judaicas de gentes de la calle del Sagell, elaborado con celo por el fiscal Juan de Fontamar.

El informe Fontamar, resultante de sigilosas investigaciones iniciadas en 1672 con la venia, que era preceptiva, del Consejo Supremo, y según autos instruidos por el inquisidor Bartolomé de Prado, imputaba a 14 vecinos de los linajes Aguiló, Bonnín, Burgos, Cortés, Fuster, Galiana, Martí y Pomar, como presuntos judaizantes por sospecharse, sólo sospecharse, a tenor de testimonios ambiguos de unos pocos testigos cristianos viejos, que prestaban servicios domésticos en casas de conversos, tratados según decían intachablemente por ellos, o que habitaban en la calle del Sagell o en su entorno y que manifestaron que observaban ceremonias que les parecían judaicas, explicitadas en los 33 capítulos del Informe Fontamar, en el que advertía el fiscal, «según ha venido a mi noticia todos los demás de dicha nación hebrea guardan la caduca ley de Moisés", por lo que suplicaba al inquisidor general que autorizara la apertura, "con todo recato y secreto, de una instrucción contra todos los de dicha nación, pues hacen un mismo cuerpo", para indagar los hechos hasta pronunciar setencia definitiva y, en su caso, "ejecutar las personas y bienes que resultasen culpados... para que a ellos sirva de castigo y a otros de exemplo".

El Consejo Supremo, se tomó con sosiego la acusación Fontamar responsabilizando criminalmente a toda la comunidad chueta de judaizar, de manera que transcurrieron casi cuatro años hasta que el 18 de agosto de 1677 se recibió en Mallorca el «procédase», la venía preceptiva del inquisidor general. Con ello la investigación, que estaba en punto muerto, se aceleró. La primera orden de arresto se libró el 28 de agosto contra Pedro Onofre Cortés de Guillermo, alias «Moxina» y luego, según avanzaba la indagación, se ordenaron otros arrestos que, no obstante, no se llevaron a efecto, mantenidos en secreto y dejados en suspenso, incluso el de Pedro Onofre, hasta que el 13 de octubre se recibió el placet del Consejo Supremo para realizar los arrestos. Estos primeros arrestos sorprendieron a la comunidad chueta, que discurría absolutamente ajena a la larga y sigilosa tramitación inquisitorial, y motivaron una penosa cadena de mu- 
tuas delaciones, al punto de que en enero de 1678 había arrestadas una veintena de personas y el 12 de febrero, día de Santa Eulalia, patrona de la parroquia del barrio, se procedió a arrestar otros treinta.

Los arrestos del día de Santa Eulalia, sin precedentes por el número de arrestados, conmocionaron la pequeña comunidad, totalmente abatida y desconcertada, presa de la desmoralización, estupefacta y empavorecida. Años después se reveló lo acontecido. «Haviendo reconocido con las demás gentes de la calle del Sayell, Bolsería y Platería, que estaban descubiertos - declaró Gabriel Cortés alias "Pota" procesado en 1688 por segunda vez-, y que no podían escapar determinaron de venir todos a pedir (voluntariamente) misericordia (al Santo Oficio)».

Parece que se acordó que primero se presentaran al Santo Oficio los hijos menores de edad, instruidos para que «no testificasen (que no delatasen) más que a sus padres y parientes más cercanos", y para decir "que sólo con ellos se havían comunicado como judíos». El plan, conocido como «Complicidad de los de la calle del Sagell», se llevó a la práctica según lo acordado, y comportó en el curso del mes de abril otros arrestos masivos, al punto de que finalizado el mes estaban en las celdas de la Inquisición y en locales habilitados en casas de familiares de la Inquisición, más de 200 judaizantes de 13 a 80 años de edad.

Tras un año de reclusión, en el que se dispensó a los presos un trato excelente en lo tocante a la manutención (la intendencia además de la ración alimentaria reglamentada, que consta en los registros día a día, suministraba las viandas y los enseres solicitados para guisarlas en las celdas), a la atención sanitaria y al recreo y comunicación entre los reclusos, aunque estaba severamente vedada en las reglas de la Inquisición, basadas en la incomunicación absoluta de los procesados. ¿Mediaron sobornos? Por supuesto. Se sabía y se disimulaba. Y entre abril y mayo de 1679 se celebraron cuatro autos de fe para reconciliar a 210 penitentes (127 mujeres, 103 hombres), sin que se pronunciara ninguna sentencia de cárcel o de muerte. Quedaron en libertad los reclusos, pero no hubo misericordia para ellos, porque la reconciliación aparte de las habituales penas espirituales y aflictivas, como llevar el sambenito o asistir en procesión a ciertos oficios religiosos, implicó la confiscación del patrimonio de los reconciliados, secuestrado cautelarmente desde el arresto del reo.

Confiscadas las viviendas y los haberes de los procesados, ¿cómo podían sobrevivir los reconciliados? Con la ayuda solidaria que les prestaron los chuetas no arrestados, con dineros y joyas que habían ocultado antes del arresto, y valiéndose de la complicidad de sacerdotes y cristianos viejos que cobraron en la receptoría de la Inquisición facturas falsas amaña- 
das, presentadas como deudas de los recluidos, y porque la receptoría les dio facilidades para arrendar las viviendas, sus viviendas, confiscadas. En todo caso los conversos tuvieron que afrontar y remontar tiempos muy duros, sometidos a la doble vigilancia de la Inquisición y de la Administración que, recelando fugas, sólo otorgaban mediando fianzas y a cuenta gotas las licencias necesarias para salir de Mallorca para negociar.

En tal coyuntura, en julio de 1685, Rafael Cortés de Alfonso, alias "Cabezaloca», botiguero, reconciliado en 1679, comunicó al padre Sebastián Sabater de la Compañía de Jesús, la sospecha de que su primo Pedro Onofre Cortés «Moxina», botiguero, también reconciliado en 1679 (fue el primer arrestado), judaizaba y que lo delataría si el Santo Oficio se lo requería. El padre Sabater, a petición de «Cabezaloca», trasmitió la información a los inquisidores de Mallorca, que la remitieron al Consejo Supremo. Al año siguiente, entre noviembre y diciembre de 1686, "Cabezaloca" confió en secreto, para su custodia, al padre Sabater seis papeles manuscritos, sobre conversaciones con su primo «Moxina», y cuando en septiembre de 1687 murió «Cabezaloca» en circunstancias extrañas, el padre Sabater, cumpliendo probablemente la voluntad del fallecido, entregó los papeles a los inquisidores que, enterados de su contenido, instaron otra vez la venia del Consejo Supremo para arrestar y procesar a «Moxina».

La orden del Consejo Supremo, «que se faga la causa hasta la sentencia definitiva", se recibió en enero de 1688, y en la noche del 10 al 11 de febrero «Moxina» fue arrestado. Entonces, una treintena de conversos que frecuentaban la compañía de Rafael Valls «Mayor», jabonero de oficio, ilustrado y prestigioso, temiendo ser arrestados, decidieron escapar de Mallorca, a cuyo efecto contrataron sigilosamente por 500 pesos, equivalentes a 566 libras moneda de Mallorca, la nave «Cisne» del patrón Vullis, para navegar a Holanda o a Inglaterra. El 7 de marzo, Vullis avisó que zarparía aquella noche de mediar buen tiempo, pero cuando los conversos estaban a bordo, el mar se encrespó y como no amainaba y el patrón, aunque le ofrecieron doblarle el precio, no quería zarpar, desembarcaron en torno a medianoche, con la sorpresa de que al llegar sobre las dos de la madrugada, pues la nave estaba anclada en el entorno de Portopí, a sus casas en el Sagell y la Bolsería, les esperaban ministros del Santo Oficio para arrestarles. ¿Qué había acaecido? Fue cosa del azar. Un convecino, Jordi Picó, entró en la casa de Onofre Cortés de Agustín, uno de los comprometidos, al oír insistentes lamentos de la anciana abuela de Onofre, que le dijo: «Se han ido y me han dejado». Picó avisó al aguacil Puigdorfila, que vivía en el barrio, y el alguacil había alertado a los inquisidores. De esta manera, se frustó lo que la Inquisición interpretó e instruyó como "Segunda complicidad de los de la calle del Sagell». 
Entre marzo y mayo, la Inquisición arrestó y abrió proceso a unas 120 personas. Tres años después, instruidas las causas, se celebraron del 7 de marzo al 2 de junio de 1691 cuatro autos de fe, con el resultado de 39 procesados puestos en libertad por falta de probanzas, 39 penitentes reconciliados, 4 penitentes difuntos quemados en huesos, 4 fugitivos procesados en ausencia y quemados en estatua, 33 penitentes sentenciados a muerte en persona y 3 penitentes sentenciados a morir quemados vivos como judaizantes obstinados. Como en el auto de fe de 1675, la concurrencia de gentes fue masiva, tanto en las calles durante las procesiones como en los actos de lectura de las sentencias, organizados como ceremonias espectaculares y, sobre todo, en la ejecución de las sentencias, ejecutadas dado el gran número de sentenciados, en un dilatado campo sobre el mar, al pie de la colina del castillo de Bellver, ante miles de personas llegadas en su mayor parte de los pueblos, acampadas en el entorno desde el día anterior.

No precisa apelar a la libertad de conciencia para deplorar y condenar los procesos inquisitoriales. Los de 1679, por su tramitación y secuelas, fueron un despojo depredador de los conversos. ¿A cuánto ascendió el botín? Se considera que a 1.416.276 pesos, que equivalen a 1.605.348 libras moneda de Mallorca, lo que acredita la riqueza, que sorprendió a los más, de muchos de los conversos; y como está documentado que el remanente neto de las confiscaciones fue de 745.638 pesos, equivalentes a 845.180 libras, se deduce que el 47,35 por 100 del total confiscado, la receptoría de la Inquisición lo invirtió en saldar deudas pendientes de los procesados, en su manutención, atenciones sanitarias y abastecimiento, y en costos judiciales y otros gastos dimanantes del proceso.

Como el rey tomó en consideración la demanda del Consell General de Mallorca, en el sentido de que la salida de Mallorca de una masa de activos monetarios tan importante sería una sangría financiera susceptible de arruinar el reino, se convino una distribución razonable de las 845.180 libras del beneficio neto obtenido de las confiscaciones, destinando el 4,20 por 100 (35.498 libras) al Consejo Supremo de la Inquisición, como compensación parcial de las subvenciones anuales que solía otorgar al Tribunal de Mallorca; el 13,44 por 100 (113.592 libras) a reconstruir y a ampliar la sede de la Inquisición de Mallorca, en estado de ruina total tras décadas de abandono por falta de dineros; el 33,52 por 100 (283.304 libras) a constituir un fondo patrimonial que rentara las 10.000 libras anuales necesarias al pago de salarios y a otros gastos del Tribunal de Mallorca, que hasta entonces no tenía patrimonio propio y se financiaba con subvenciones del Consejo Supremo o de otros Tribunales como el de 
Valencia; y el 48,84 por 100 (412.169 libras) a la Procuración Real de Mallorca, para que lo invirtiera en gastos a realizar en el reino, es decir, en Mallorca, en Menorca y en Ibiza-Formentera.

Las sentencias de 1691 fueron de extraordinario rigor. Los ejecutados en persona aquel año, sólo en tres días de aquel año, representan el 26 por 100 del total de condenas a muerte en persona pronunciadas por la Inquisición de Mallorca durante 203 años de represión (de 1488 a 1691), desde la instauración de la Inquisición reformada en Mallorca. En 1691, se aplicó la pena de muerte por estrangulación a garrote, a penitentes que insistían en su catolicidad, sólo por haber practicado sin intención de judaizar, usos que el Tribunal consideraba judiadas. El padre Garau, que en aquel trance asistió espiritualmente a algunos reos, comenta que la comunicación de las sentencias «cogioles a los más de improviso, casi todos esperanzados en la que llamaban piedad del Tribunal». No era, desde luego, la sentencia que esperaban ni mucho menos la que merecían. De los 36 condenados a muerte 3 (Rafael Valls "Maior», Catalina Tarongí, Rafael Benito Tarongí) quemados vivos, perseveraron con entereza y dignidad en sus convicciones, 7 ( 5 mujeres y 2 hombres) se mantuvieron hasta el final «impenitentes negativas», sin abjurar, 2 (uno de ellos Pedro Onofre Cortés «Moxina») se proclamaron adictos al judaísmo pero en última instancia, ya en capilla, abjuraron, y los 24 restantes, aunque la sentencia los condena por judaizar, siempre manifestaron que ni eran judíos de creencias ni tenían conciencia de haber judaizado.

Lo acontecido en torno a los procesos de 1679 y 1691 fue aflictivo y deplorable; no obstante, siendo ello tan repudiable, lo más nefasto para la sociedad de Mallorca fue el legado de rencores. Existía, en efecto, un conflicto, un preocupante conflicto sociológico de mala relación entre los descendientes de judeoconversos y los cristianos viejos, pero era un conflicto en vías de solventarse, como se estaba solventando o se había solventado en otros lugares de España y en otros estados de Occidente. En Mallorca, los dos centenares de apellidos de la época de Fernando el Católico se habían reducido en 1679, por emigración de los conversos o por extinción natural de familias o por su integración en la comunidad mayoritaria cristiano-vieja, a una quincena de apellidos; pero la tensión emocional generada en torno a los procesos y la gravedad de las condenas, enconó la intolerancia y el rechazo entre las dos comunidades y ahondó la brecha que las separaba, hasta convertirla en fractura, y contribuyó a que perdurara largamente, durante décadas, un problema que carecía de sentido racional y que tenía que desvanecerse, como venía desvaneciéndose, con el paso del tiempo, dando tiempo al tiempo. 


\section{EL LARGO CONTENCIOSO POR LA IGUALDAD}

Las secuelas de los procesos repercutieron con efectos traumatizantes en la sociedad mallorquina. Se popularizó la expresión "des carrer del Sagell» y el término "xueta», judío, dichos con ánimo de menosprecio, vejatorio e infamante, y la preocupación que ya existía por la limpieza de sangre se hizo obsesiva, acaso sobre todo entre el campesinado de las villas y en sectores de la menestralía, que incorporaron en sus estatutos normas prohibiendo la entrada en sus gremios de «descendientes ni consanguíneos de los que se llaman des carrer del Sagell» o bien de "descendientes de moros ni de judíos ni de personas que han sido penitenciadas por el Tribunal de la Inquisición", cual fue el caso de los horneros (1695), de los cirujanos y barberos (1699), de los sastres (1701), de los esparteros (1702), de los carpinteros (1705), de los escribanos y procuradores (1705) o de los pintores y escultores (1706), y también de la Universidad Literaria Luliana en sus Estatutos de 1499.

La comunidad chueta, despojada de sus haberes y abatida por las experiencias vividas, tendió a replegarse en sí misma y a fortalecer su unidad y su solidaridad; y como en otras ocasiones demostró su capacidad para sufrir y aguantar malos tiempos, y para recuperarse en las coyunturas más desesperanzadoras. La animadversión de los menestrales, no debió afectarles en demasía, al menos laboralmente, porque tenían mayoría en las corporaciones rectoras de sus dedicaciones más habituales: marchantes, merceros, pasamaneros, plateros y terciopeleros, si bien en 1689 estos últimos, en cuyo gremio también eran mayoría, se dividieron en «velluters del carrer del Sagell» y en "velluters de fora carrer».

En 1708, treinta y ocho particulares de la calle del Sagell, con buena voluntad participativa, aportaron a la colecta organizada bajo la denominación "donatiu voluntari», para contribuir a financiar una expedición a Menorca, 150 libras moneda de Mallorca, que sumadas a las 467 libras donadas por los gremios chuetas ascendieron a 687 libras, lo que significa que los chuetas contribuyeron con el 4 por 100 del importe total del «donatiu voluntari» (15.418 libras) y el 3 por 100 del total insular (20.451 libras). Y sólo tres de los contribuyentes, los más pudientes, Baltasar Valentí Forteza, Gabriel Rafel Aguiló y Agustí Alfonso Cortés, aportaron el 42 por 100 de la contribución chueta.

Baltasar Valentí Forteza, los hermanos Gabriel y Onofre Aguiló, Bernat Aguiló y Gaspar Piña, participaron en la conspiración nobiliaria de 1711 para reponer en Mallorca la soberanía felipista, derribada en 1706 por los austriacistas con la apoyadura decisiva de la flota angloholandesa del al- 
mirante Leake, que dominaba hacía tiempo hegemónicamente en el Mediterráneo. La conspiración tramada por don Juan Sureda, el marqués de Bellpuig y por otros componentes de la nobleza y del caballerato de Mallorca, mayormente felipistas, abortó y los conspiradores fueron sancionados. ¿Eran felipistas los chuetas? Los conversos, habitualmente, estuvieron al margen de los avatares político-sociales y pienso que, también en esta ocasión, no participaron en la tensión felipismo-austriacismo como comunidad. La participación de los citados debió ser opción individual, para aportar fondos, en su momento, y por afección felipista y buena relación con algunos conspiradores nobles.

Los datos de la talla recaudada en 1721 , que gravó en un 0,21 por 100 los patrimonios netos de todos los contribuyentes, incluidos los eclesiásti$\cos$, brindan una perspectiva de aproximación a las circunstancias vitales de la comunidad chueta transcurrida una generación, treinta años después de la hecatombe de 1691. Todos los contribuyentes residían en las parroquias Santa Eulalia $(64,14$ por 100$)$ y San Nicolás $(35,86$ por 100$)$, concretamente en la Bossería, en el Sagell y en la Argentería (en la actualidad calles Jaime II, Bolsería, Platería), en las manzanas denominadas Font de Sant Cristofol, de la Bossería, Taula de la Pescadería, de Juan Deya forner, de Pere Onofre argenter, del cantó den Pomar, Volta de Tarongí y Carnisseria demunt, en la parroquia Santa Eulalia; y en la parte contigua al Sagell de la parroquia San Nicolás, manzanas nombradas de la Inquisición, del doctor Forteza, costa de Santacilia, convent de la Misericordia y Volta del Mercat (en la actualidad calles Monjas y San Bartolomé y cuesta Santacilla). Legalmente nada impedía a los conversos habitar fuera del barrio, pero en su ámbito tenían a mano los centros comerciales (Carnisseria demunt, Pescaderia, Casa del Sagell, Cuartera del Forment, Banc del Oli, Pes del carbó, plasa de los Cols, Pes de la Farina, plasa del Pà) y el centro político-administrativo, en la Plasa de les Corts (Ayuntamiento, cortes judiciales, oficinas de las curias señoriales).

Tras la catástrofe de 1691, en la vida cotidiana, los conversos adecuaron sus hábitos a las formas de vida de los cristianos viejos, sobre todo en condimentos y aderezo de las viandas, renunciando a prácticas conservadas por atavismo y que solían ser miradas con recelo por los cristianos viejos; pero mantuvieron su sentido de familia y su respeto reverencial a los mayores, y su afección a la hospitalidad y su solidaridad comunitaria, en relación al amparo de enfermos desatendidos y ancianos desvalidos. «Regularmente ninguno de los de esta generación que se titulan de la calle -refería en 1774 Miguel Cayetano Soler apoderado de la ciudad de Palma - va al hospital como los demás pobres enfermos. Se reparten entre sí (los enfermos) o contribuyen en cierta cantidad para el médico, ci- 
rujano y botica, y nombran una persona que recorriendo las casas de los de la calle recoge la limosna o contribución para los gastos y empresas, así comunes como particulares, que cada uno satisface en proporción de su caudal, como si entre todos no compusiesen más que una familia".

El patrimonio neto de la comunidad chueta en 1721 importaba 267.792 libras moneda de Mallorca, y el 46,50 por 100 de los contribuyentes poseían un patrimonio clasificable como pequeño (patrimonios de 1 a 499 libras), el 44,50 por 100 tenían patrimonios medianos (patrimonios de 500 a 4.999 libras), el 7,50 por 100 patrimonios grandes (patrimonios de 5.000 a 19.999 libras) y el 1,50 por 100 eran mayores contribuyentes (patrimonios de más de 20.000 libras). Este perfil patrimonial es más equilibrado que el de 1636, por la disminución de los pequeños patrimonios (del 60 al 46,50 por 100), por el aumento de los patrimonios medianos (del 32 al 44,50 por 100) y sobre todo porque sólo 12 de los contribuyentes estaban por debajo del índice de pobreza (patrimonios de menos de 50 libras); perfil equilibrado pese a una concentración patrimonial de cierta consideración (el 4 por 100 de los contribuyentes detentaba el 37,50 por 100 del patrimonio y 2 de los contribuyentes, los hermanos Gabriel y Onofre Aguiló, antepasados de los Aguiló de la calle San Bartolomé, poseían más de la quinta parte del patrimonio total).

La comunidad conversa con un patrimonio neto que significaba el 1,75 por 100 del patrimonio catastral insular (15.238.000 libras), mientras demográficamente no llegaba al 1 por 100 de la población, tenía un estar económico bonancible y estable, aunque alejado del enorme volumen patrimonial de 1679 , de antes del despojo. La gran propiedad estaba en manos de la nobleza, inexistente en Mallorca hasta el siglo XVI, beneficiada mayormente por el proceso señorializador de los siglos XVI y XVII (6 nobles detentaban el 6 por 100 del patrimonio catastral) y el mayor propietario, don Juan Sureda, marqués de Vivot, poseía el 1,32 por 100 (patrimonio neto 204.000 libras) del patrimonio catastral de Mallorca.

Los chuetas, ¿cómo remontaron la catastrófica situación heredada? Con resignación, austeridad, laboriosidad, intuición y ojo clínico y capacidad negociadora; además continuaron ejerciendo, como antes de la hecatombe, las dedicaciones más rentables por sus márgenes gananciales, como el pequeño comercio ambulante (buhoneros) y estante (botigueros y marchantes de tienda abierta), el tráfico de importación/exportación, la intermediación en compra-ventas, la inversión mobiliaria en préstamos y créditos a intereses legales, el cambio de monedas como cambistas y los seguros marítimos.

Además, superada la prueba de fuego inquisitorial, seguros de su afianzamiento en el catolicismo, se arriesgaron a participar en una nueva área. 
económica: la inversión en fincas rústicas. Antes, desde tiempos, gustaban de comprar para su solaz pequeñas parcelas de huerto en las cercanías de la ciudad, pero nunca fincas rurales; ahora, comprarán fincas rurales bien situadas, no para laborarlas ellos directamente sino para gestionarlas mediante "amos" o colonos, o cediéndolas en arrendamiento. De esta manera continuaron ejerciendo de negociantes, su dedicación principal como generadora de ingresos, y por añadidura ejercieron de terratenientes, no de labradores.

Pienso que en este punto, la adquisición de fincas rústicas, el ejemplo de los hermanos Gabriel y Onofre Aguiló, puede ser ilustrativo. Eran hijos de Pedro Juan Aguiló, un botiguero acomodado de tejidos, y de Isabel Cortés, reconciliados en 1679 con confiscación del patrimonio familiar por el Santo Oficio, cuando ellos eran de pocos años. Pedro Juan, pudo recuperar su botiga de tejidos mediante convenio con la receptoría de la Inquisición y recomenzó con abnegación su laborar, y sus hijos Gabriel y Onofre optaron por dedicarse a pequeños negocios. $Y$ tuvieron éxito.

Gabriel, compró en 1696 a la receptoría de la Inquisición la que tenía que ser su casa, en el Sagell, por 800 libras, y desde 1696 a 1742 realizó operaciones mobiliarias, invirtiendo en efectos públicos de la Consignación (Gabela de la sal, Imposició del cuyram, Dret de la mercadería, etc.), en deuda municipal de las villas foráneas y en créditos a particulares por un total de más de 50.000 libras; y al mismo tiempo realizó durante dicho período inversiones en fincas rústicas por un total de unas 34.000 libras. Fueron compras selectivas, en las cercanías de la ciudad: diversas parcelas a extramuros de la Porta de Jesús (unas 4.000 libras), los predios Rafal Son Puig (unas 8.000 libras) y Rafal Son Moix Blanch (unas 10.000 libras) en el camino de Son Rapinya, y un huerto grande en el camino de Bunyola (unas 900 libras). Fuera del término de la ciudad adquirió el predio Son vich (unas 11.000 libras) en Calvià, formado por varias fincas contiguas.

Onofre Aguiló, que también se instaló en el Sagell, en una casa comprada en 1695 a la receptoría de la Inquisición por 620 libras, realizó de 1715 a 1742 inversiones mobiliarias por importe de más de 22.000 libras en fondos públicos de la Consignación (Victigal del oli), deuda de villas foráneas y créditos a particulares; y desde 1710 a 1741 realizó inversiones inmobiliarias que totalizaron unas 20.000 libras en fincas rústicas, en tres áreas territoriales de porvenir: a extramuros de la Porta del Camp, en el inmediato Molinar de Llevant (9 molinos con huerta y algunos con vivienda, unas 3.750 libras); a extramuros de la Porta de Jesús, el cercano e importante predio Son Cotoner (unas 9.000 libras), actual barriada de Son Cotoner de Palma, y el predio contiguo Son Pizà, ambos lindantes con 
Son Moix Blanch comprado por su hermano Gabriel; y en el vecino término de Esporles los predios Rafal Pou y Forn de Vidre y otras casas y parcelas (unas 7.000 libras).

La adquisición de suelo rústico la hícieron preferentemente «per via de establiment», es decir, mediante contratos de enfiteusis rural que por un precio de entrada y el pago del censo anual convenido, les otorgaba la posesión o dominio útil sobre la finca, reservándose el dueño la propiedad o dominio directo. Como eran fincas en dificultades, hipotecadas con diversos censos, los hermanos Aguiló procuraban redimir cuanto antes los censos y asumir a la brevedad posible el dominio directo, comprándolo al dueño para detentar la propiedad plena, la útil y la directa, de la finca. En otros casos la finca la adquirieron "via compra», de propietarios en precariedad, con la finca hipotecada; en este supuesto ejercían de inmediato el dominio pleno y para sanear la finca liberaban con la prontitud posible los censos hipotecarios.

Gabriel Aguiló poseía con mucha diferencia, según se verifica en la talla general de 1721, el mayor patrimonio (patrimonio neto, 31.725 libras) de la comunidad chueta y, conjuntamente con el patrimonio de su hermano Onofre, significaban el 20 por 100 del total patrimonial de dicha comunidad. Ambos hermanos, que habían participado diez años antes, en 1711, en la abortada conspiración felipista contra la soberanía del archiduque Carlos de Austria, se relacionaban económicamente con componentes de la nobleza (marqués de Campofranco, marqués de la Torre, marqués de Vivot, conde de Montenegro), con casi todas las comunidades parroquiales de la ciudad y casi todas las comunidades conventuales y con particulares de la ciudad y de las villas foráneas, y en los instrumentos notariales se les da, a veces, el tratamiento de «Vosa Mercè».

El nieto de Onofre Aguiló, también llamado Onofre, trasladó en 1752 el domicilio familiar adquirido en 1695 en la calle del Sagell, a la actual calle de San Bartolomé, dentro del barrio, esquina cuesta de Berga, donde en el solar de varias casas edificó la nueva residencia solariega, enajenada hace pocos años por los herederos de don Eugenio Aguiló Aguiló, sucesor en línea directa de Onofre Aguiló. Herederos que conservan tierras del predio de Son Cotoner, ahora populosa barriada de Son Cotoner, primera adquisición importante de Onofre Aguiló en la cercanía de la ciudad, en el lugar entonces denominado del «Viñet», comprada en 1716 a don Francisco Boix de Berard y Cotoner, sacerdote.

Por entonces, mediado el siglo XVIII, la comunidad chueta estaba desazonada porque siendo y sintiéndose católicos consecuentes en una sociedad de católicos, satisfaciendo con puntualidad los numerosos im- 
puestos, ayudando financieramente en sus apuros a la Administración que no solía agradecer la ayuda, y comportándose en sus relaciones dentro de la más estricta legalidad como probos ciudadanos, se les marginaba de la vida política y de la participación en la función pública, las corporaciones menestrales les discriminaban, la iglesia de Mallorca trababa todo lo posible su acceso a las órdenes sacerdotales y su entrada en órdenes religiosas, la Universidad Literaria les cerraba sus puertas, persistía el ambiente de recelo y la consideración de su ascendencia judeoconvesa, que ellos reconocían y asumían con mucha dignidad, mirada como estigma infamante e inhabilitador, lo que vulneraba la pragmática de Granada promulgada por los Reyes Católicos el 20 de septiembre de 1501, que mantenía vigencia y que limitaba la inhabilidad para ocupar empleos públicos, de los descendientes de penitentes reconciliados por el Santo Oficio a la primera generación, a los hijos, por línea femenina y, en la segunda generación, a los nietos, por línea masculina. Y a la sazón discurría la tercera generación chueta, desde los procesos de fines del siglo XVII, por lo que, según dicha pragmática, podían acceder a cualquier empleo público.

En 1770 un comisionado de la comunidad, tanteó muy confidencialmente en Madrid el otorgamiento de una resolución real sobre su derecho a ser considerados en todo como los demás vasallos, pero se le advirtió que tal resolución tenía que gestionarse por conducto del Real y Supremo Consejo de Castilla, en el que había consejeros expertos en la problemática de la Corona de Aragón, que se requería además informe de la Audiencia de Mallorca y que los trámites llevaban su tiempo y los consiguientes gastos procesales, aparte de que precisaba aportar probanzas en apoyo de lo que se demandaba.

En diciembre de 1770 una comisión de cinco miembros titulados "Diputados de los individuos de la calle de la ciudad de Palma», ya había instado con todo sigilo y tenía en su poder certificados de buena conducta de rectores parroquiales y de responsables de distintas entidades públicas, sobre la importancia de sus actividades en diversas ramas; pero la demanda formal, el «Memorial a Su Magestad de los individuos llamados de la calle de estirpe hebrea" solicitando ser admitidos como españoles de nación y católicos de condición, «en todos los gremios, empleos y oficios públicos y privados como los demás vasallos honrados pese a su estirpe hebrea», sólo fue presentado y registrado el 12 de febrero de 1773.

La providencia del Consejo Supremo interesando de la Audiencia de Mallorca informe sobre el citado "Memorial» sorprendió, desconcertó y disgustó grandemente a la Administración y a las Instituciones de Mallorca, 
que no sospechaban semejante papeleta, preparada y tramitada la demanda calladamente, en secreto. Todas las Instituciones que ejercian los poderes (Ayuntamiento de Palma, síndicos de las villas foráneas, Real Audiencia, Cabildo diocesano, Universidad literaria), unidos en un frente solidario a modo de Cuádruple Alianza, remitieron al Consejo Supremo amplios y eruditos informes rechazando la pretensión de igualdad de los individuos de la calle, como infundada y contraria no sólo a las esencias y al progreso sino a la misma existencia de Mallorca.

Jurídicamente, sin embargo, como sostenía el informe de don Pedro Rodríguez de Campomanes fiscal del Consejo Supremo, la pretensión de los demandantes se ajustaba a derecho, las providencias de la Audiencia de Mallorca que legalizaron normativas discriminatorias contra los chuetas se pronunciaron contra el espíritu de las leyes vigentes en la Monarquía española e infringiéndolas, y la continuidad de la dialéctica y del lenguaje cristianos nuevos/cristianos viejos, no tenía sentido y dañaba los intereses del Estado, por lo que concluía el fiscal: «Por principios legales y políticos la pretensión de Juan Bonnín (primer firmante de la Memoria) y consortes es bastante clara y fundada».

En el curso del largo y apasionado contencioso, las instituciones de Mallorca sugirieron o formularon propuestas peregrinas en orden a solventar la cuestión debatida, imcompatibles con la ideología del despotismo ilustrado entonces dominante en la Administración central y centralista española, como el traslado forzoso de toda la comunidad chueta a la ciudad de Alcudia o a las islas de Menorca o de Cabrera y, caso de desestimarse dichas propuestas, su dispersión a modo de diáspora por lugares de la España interior, de la España profunda.

¿Qué se pretendía con el desahucio de los chuetas? Todo serían ventajas. Se resolverían de una vez, se argumentaba, tensiones que llevaban camino de eternizarse, se recuperaría el centro urbano ocupado por el barrio, se sanearía un área tan privilegiada por su ubicación en el corazón de la ciudad, mejoraría la imagen de la ciudad expulsando a los chuetas que ya no eran necesarios. «En Mallorca sobran los cristianos viejos - afirmaba el agente del Ayuntamiento de Palma en un comunicado al Consejo Supremo de Castilla-, para cuantos gremios y oficios menestrales necesita la vida humana, y ójala hubiese destinos para muchos pobres que viven a expensas de la república». Sobraban los chuetas.

Las propuestas de expolio y expulsión, motivaron perplejidad e inquietud en las gentes de la calle. Pero los consejeros ilustrados del Consejo Supremo de Castilla, negociado asuntos de territorios de la Corona de Aragón, que debian informar las propuestas, no compartían soluciones tan 
sumarias y expeditivas, propias de tiempos pasados. Sin embargo, en cualquier sistema de gobierno el ejercicio del poder obliga a considerar los principios ideológicos y a tener en cuenta las exigencias políticas cotidianas, entendido el ejercicio político como el arte de promover lo posible.

Y en la cuestión que se debatía, sin mengua del derecho de la comunidad de la calle, se requería valorar asimismo la postura de rechazo unánime, obstinada e irreductible de las Instituciones que ejercían el poder en Mallorca, y la reflexión expuesta por los oidores de la Audiencia de Mallorca: «Nadie puede esperar de Vuestra Majestad, sin hacerle agravio, que por contentar a 300 vecinos de sangre infecta quiera sumergir en amargo llanto a 30.000 familias de sangre limpia», reflexión que condicionó las deliberaciones del Consejo Supremo si no con efectos resolutorios sí con efectos dilatorios, muy dilatorios.

Transcurridos años no se promulgó, como se solicitaba en la demanda de 1773 con la que se inició el contencioso, una real cédula igualando las oportunidades de los individuos de la calle con las de los otros vasallos honrados de Mallorca, sino tres células reales, una de Madrid 10 de diciembre de 1782, mandando que «a los individuos llamados del barrio de la calle de la ciudad de Palma no se les impida habitar en cualquier otro sitio de la ciudad de Palma o isla, sino que se les favorezca y otorgue toda protección y que no se les insulte y maltrate»; otra cédula de San Lorenzo el Real, de 9 de octubre de 1785, declarando a «tales individuos vulgarmente llamados de la calle aptos al servicio de mar y tierra y para cualquier servicio del Estado»; y una tercera cédula de Aranjuez, 13 de abril de 1788, disponiendo la idoneidad de los citados individuos «para exercer las artes, oficios y labranza del mismo modo que los demás vasallos del estado general del reyno de Mallorca, sin que por ningún motivo se les impidiera emplearse en dichas ocupaciones".

Habían discurrido quince años desde la primera demanda, se reconocía y se legalizaba parte de lo solicitado. La comunidad chueta sentía satisfacción por el desenlace largamente deseado y esperado pero, en la vivencia cotidiana de Mallorca, ¿qué? En la vivencia cotidiana las Instituciones aplicaron, respecto a lo ordenado en las cédulas reales la vieja práctica administrativa de «Se acata respetuosamente lo mandado y que no se cumpla de momento». Pero algo cambiaba a duras penas, muy lentamente, en la sociedad de Mallorca, aferrada a consabidos tópicos y prejuicios.

La opinión mayoritaria arropaba resueltamente la postura de las Instituciones de Mailorca, pero el pensamiento ilustrado de Mallorca no la compartía o la compartía con reparos. La Sociedad de Amigos del País, inte- 
grada por socios de la nobleza y de la burguesía, fundada en 1778, cuando al socaire del contencioso la pasión antichueta alcanzaba su clímax, se abrió precisamente entonces, a la tolerancia de chuetas y en la fiesta de Reparto de Premios de 1779, resultaron premiados en la sección de Dibujo, José Bonnín y Francisco Aguiló, y a las aulas de la Sociedad asistían alumnos chuetas, que compartían actividades y estudios con los otros alumnos.

En el curso del siglo XIX, descendientes de judeoconversos participaban en la vida política y ocupaban cargos en la gestión pública, y ejercían con gran aceptación profesiones liberales y, por supuesto, mediaron en el desarrollo y progreso de la economía isleña. Chuetas intervenían en la Junta para la construcción de una plaza de toros (1863), en la Junta de gobierno del Banco Balear (1866), en la Comisión histórico-artística del Ayuntamiento (1867), en la sociedad anónima el Cambio Mallorquín (1876), en la Sociedad de Ferrocarriles del Centro y del Sudeste de Mallorca (1876), en la Fundación Centro Farmacéutico (1876), en la Harinera Balear (1879), en la Empresa para la canalización de las aguas potables (1879), en La Isleña, Empresa marítima de Vapor (1879), en la Compañía de Almacenes Generales de Depósito (1879), etc... En tales y en otras entidades, empresarios de la nobleza y de la burguesía, muchos de ellos chuetas, se afanaban en el progreso de Mallorca y en su personal beneficio.

No obstante, en 1877, José Tarongí y Cortés, un joven y arriscado sacerdote, polémico y hábil polemista, en el libro-denuncia Algo sobre el estado religioso y social de la isla de Mallorca, fustigó en lenguaje crudo las "preocupaciones de clase" de la sociedad mallorquina a las que, según comentaba «El Anunciador Balear», periódico de Palma, trataba de asestar «el golpe de gracia». José Luis Aguiló Cortés, descendiente en línea directa de Onofre Aguiló, confío a José Tarongí, compañero del mismo curso de Bachillerato en el Instituto Balear, su desacuerdo con el propósito de provocar debate sobre las «preocupaciones de clase», debate que, por cierto, encontró mayor eco en los medios de comunicación social peninsulares que en los mallorquines.

José Luis Aguiló opinaba, opinión probablemente muy extendida entre los chuetas, que pese a todo no era ni oportuno ni deseable airear las «preocupaciones», porque cuando la cuestión se moderaba sensiblemente podía contribuir a enconarla y dañar la convivencia social, lo que no sería bueno. «Una de las principales causas de mi tristeza hijos míos - anota en sus Memorias cuando acababa de cumplir 41 años- es que no he sabido mirar con indiferencia esta cuestión tan trascendental y revelaros ciertos 
misterios de la vida mallorquina. Feliciano (su primogénito) ha preguntado, ¿por qué don Francisco Forteza no predica? ¿por qué no le han hecho cura párroco en alguna parroquia, él que hizo unas oposiciones tan brillantes?.. Hoy te contesto: los mallorquines no nos quieren porque dicen que somos descendientes de judíos, cuando hace tres siglos que somos cristianos y que somos iguales ante Dios por el bautismo».

José Luis Aguiló, primo del eminente investigador de la historia de Mallorca Estanislao de Koska Aguiló, era abogado y hacendado rico (su patrimonio valorado en 1877 ascendía a más de un millón de pesetas), moderado en gustos y preferencias y de honda religiosidad, y sentía en sus carnes las "preocupaciones», pero a fines de 1890 admite: «Hoy han variado las cosas y la forma agresiva y odiosa que tenían antes". Ahora, transcurrido un siglo, aunque a veces se diga que las «preocupaciones» todavía colean, están instaladas en el pasado, un pasado conflictivo, de luces y sombras, que merece remembranza porque está vinculado a las esencias, peculiaridades e identidad de Mallorca y es parte de la historia grande de Mallorca. 